This document is the accepted manuscript version of the following article:

Huang, W., Fonti, P., Larsen, J. B., Ræbi1d, A. R., Callesen, I., Bjerregaard

Pedersen, N., \& Hansen, J. K. (2017). Projecting tree-growth responses into future

climate: a study case from a Danish-wide common garden. Agricultural and Forest

Meteorology, 247, 240-251. https://doi.org/10.1016/j.agrformet.2017.07.016

This manuscript version is made available under the CC-BY-NC-ND 4.0

1icense http://creativecommons.org/1icenses/by-nc-nd/4.0/

\title{
Projecting tree-growth responses into future climate: a study case from a Danish-wide common garden
}

\begin{abstract}
Weiwei Huang ${ }^{1, *}$, Patrick Fonti ${ }^{2,3}$, Jørgen Bo Larsen ${ }^{1}$, Anders Ræbild ${ }^{1}$, Ingeborg Callesen ${ }^{1}$, Nanna Bjerregaard Pedersen ${ }^{1,4}$, Jon Kehlet Hansen $^{1}$
\end{abstract}

${ }^{1}$ Department of Geosciences and Natural Resource Management, The University of Copenhagen, Rolighedsvej 23, DK-1958 Frederiksberg C, Denmark;

${ }^{2}$ Swiss Federal Institute for Forest, Snow and Landscape Research WSL, Zürcherstrasse 111, CH-8903

Birmensdorf, Switzerland;

${ }^{3}$ Siberian Federal University, Svobodny av. 79, 600041 Krasnoyarsk, Russia

${ }^{4}$ Environmental Archaeology and Materials Science, National Museum of Denmark, I.C. Modewegsvej, Brede, DK-2800 Kgs. Lyngby, Denmark.

\footnotetext{
* Corresponding author.
}

Tel.: +45 35321072

E-mail address: wh@ign.ku.dk (W.W. Huang). 


\section{Abstract}

Assessing growth responses to climate variations from common garden experiments is vital to identify a species portfolio matching future climate. In the present study we make use of a 50 years old common garden experiment spanning six sites with different soil types across Denmark to i) analyse climate-growth responses and resilience to drought and ii) model future growth predictions for six non-native conifers and two native broadleaved tree species. Species-specific response-functions and Superposed Epoch Analysis of drought events are used to assess differences in sensitivity to drought.

The results show that the growth of all species, except for Quercus robur L., are significantly $(P<0.05)$ and negatively correlated with summer drought from June-August in at least one of the sites, whereby Larix kaempferi (Lamb.) Carr, Abies grandis (Dougl.) Lindl., Picea sitchensis (Bong.) Carr., and Picea abies (L.) Karst. are the less resilient. Negative effects of previous warm autumn or late summer were found for $P$. abies, A. grandis, Abies alba Mill. and Pseudotsuga menziesii (Mirb.) Franco. Moreover, independently of the site conditions, our model projections of growth responses under future climate prediction (RCP4.5 emission scenario) forecast that growth of L. kaempferi, A. grandis, P. abies and Fagus sylvatica L. will be reduced by up to $10-16 \%$ by 2100 . Minor changes in growth responses are expected for $P$. sitchensis, $A$. alba and $P$. menziesii, while $Q$. robur will increase by $12 \%$.

This study demonstrates how such projections based on old common garden experiments could be used as inputs to today's forest management decisions.

Keywords: Climate change; Drought; Dendroecology; Common garden; Growth prediction 


\section{Introduction}

Today's composition and structure of European forests are often the results of management decisions taken decades or even centuries ago. These decisions were based on the assessment of the growth behaviour of the tree species at the given site and by an assessment of future needs. However, due to uncertainties related to expected shift in climate, today's forest management decisions are additionally challenged by the fact that future forest ecosystems might soon be exposed to unprecedented environmental conditions (Kirilenko and Sedjo, 2007). Current scenarios of climate change are predicting important modifications in both temperature and precipitation regimes in many regions, with in particular the intensification of extreme events and disturbances (Dai, 2013; Field et al. 2014). In Denmark for example, depending on the greenhouse gases concentration scenarios, it is expected that by the year 2100 the temperature will increase between 1 and $4{ }^{\circ} \mathrm{C}$ (Kjellström et al., 2011; Olesen et al. 2014) with an increased risk of more frequent and longer drought spells in summer (Olesen et al. 2014).

Climatic changes will profoundly affect the interactions between trees and their physical and biological environments, with important implications for tree growth and mortality (Anderegg et al., 2015). Indeed, widespread episodes of mortality have already been observed all over the globe, either directly linked to climate events (e.g. Allen et al., 2010) or indirectly through modifications of the relationships with pests and diseases (Gaylord et al., 2013; Jactel et al., 2012). Drought is one of the main constraints on forest productivity especially at soils with low water holding capacity (Weber et al., 2007). Drought events trigger abrupt growth decline (Orwig and Abrans, 1997) and mortality (McDowell et al., 2011), which may have important consequences for the structure and functions of Earth's forest ecosystems (Lindner et al., 2014). Drought episodes, defined as episodes of severe climatic water deficit, have been reported to reduce growth and induce incomplete recovery for 1 to 4 years after the event, with pervasive legacy effect most prevalent in dry ecosystems (Anderegg et al. 2015).

For appropriate species selection and management of future forest resources a deeper insight into tree growth 
and mortality responses is needed (Sass-Klaassen et al., 2016). To survive under rapid climate changes, a high degree of phenotypic plasticity and a high adaptive potential of species are required. For example, previous studies have reported that Quercus spp and Abies alba Mill. are more competitive than Fagus sylvatica L., while Picea abies (L.) Karst. is more sensitive than A. alba and F. sylvatica under dry and warm summers (Bolte et al., 2010; Leuschner et al., 2001a; Mette et al., 2013; Zang et al., 2014). It is thus expected that $P$. abies will shift northward and be replaced by more drought tolerant species at low elevations in central Europe (e.g. Quecus spp and Pseudotsuga menziesii (Mirb.) Franco) (Hanewinkel et al., 2013). Forest managers are requiring more and more indications on how growth and survival of different tree species will develop in a changing climate in order to compose an optimal species portfolio and guarantee forests are preserved to meet future generation needs (Forest Europe et al., 2015). However, this is a challenging task, since the mechanisms of responses are complex, diverse, and may differ between species. Often they do not only depend on the magnitude and frequency of the climatic factors, but also on the genetic characteristics, life stage, and life history of trees (Reichstein et al., 2013). More data on the genetic and environmental sources of variability in response to climatic events are thus necessary to address this challenge and to provide better prediction about where and how different tree species will survive and perform under future climates.

An important contribution towards a better understanding of how climate and other environmental factors can affect growth and survival of different trees species or provenances is offered by the common garden experiments. Old common garden experiments represent an important source of information, since they often combine information about the genetic background of the planted trees and provide a long history of how trees responded to the environmental conditions occurring at the site. Through the use of dendrochronological approaches, these settings represent an opportunity to evaluate how different tree species have responded to climate variations and extreme climatic events. Depending on the location of the experiments, this can be achieved even outside the natural range of the species. 
In this study we use a nationwide Danish common garden experiment established in 1964 and 1965 that included several native and non-native tree species in order to assess how growth responded to climate conditions and extremes events across sites and species. Specifically, (i) we identified which climatic factor mostly affected the growth of several species at different field trials; (ii) we assessed species differences in growth resilience to drought; (iii) and used obtained results to project growth into future climate scenarios.

\section{Materials and methods}

\subsection{The common garden experiment}

This study is based on a nationwide Danish common garden experiment (Fig. 1) established between autumn 1964 and spring 1965. The common garden was established by the Danish Forest Experiment Station, now part of the University of Copenhagen, with the aim of assessing the growth potential for high quality wood production in Denmark (Holmsgaard and Bang, 1977). The whole common garden includes 13 field trials with a total of 10 conifer and 2 broadleaved species, both native and non-native to Denmark. Each species is represented by the same Danish landrace or provenance at all sites (Holmsgaard and Bang 1977). Field trials are composed by 0.17 to 0.31 ha monospecific plots randomly located within each trial. The trees were planted at an age of two to four years and with a spacing of $1.3 \times 1.3 \mathrm{~m}$ for conifers and $1.3 \times 0.65 \mathrm{~m}$ for broadleaved species. The plots were thinned regularly in order to favour the higher quality candidates and limit competition between trees. The applied thinning regimes were from below, but over time it included also co-dominant and dominant trees. Thinning activities started at the time when the canopy of the plots closed (year 1974 to 1982 depending on site and species) and were subsequently made every four years according to the management practices of the owners of the field trials and with few exceptions in case of windfall.

\subsection{Site selection and collection of wood material}


114 For this study, we selected six field trials to cover the range of common Danish site and climatic conditions

115 (Table 1) and to share the same species (Fig. 1). The soils at the six trial sites were classified as Luvisols,

116 Arenosols and Podsols, some with seasonally shallow groundwater. Soil texture classes vary from coarse sand to sandy loam with subsoil clay percentages ranging from 2\% (1013) to 23\% (1011) (Callesen, 2003), representing water holding capacities from relatively dry to moist (Table 1). The climate at the trial sites is characterized by the typical Danish temperate climate with mild winters and cool summers. According to the Climate Research Unit grid data (CRU TS v.3.22; Harris et al., 2014), the mean annual temperature of the trial sites from 1961 to 2012 ranged between 7.7 and $8.5^{\circ} \mathrm{C}$, while precipitation was fairly well distributed with an annual sum ranging between 572 and $855 \mathrm{~mm} \mathrm{yr}^{-1}$ (Table 1).

Each selected field trial included six non-native conifer and two native broadleaved species, namely P.abies, Picea sitchensis (Bong.) Carr., A. alba, Abies grandis (Dougl.) Lindl., P. menziesii, Larix kaempferi (Lamb.) site, with the exception of $P$. sitchensis (at site 1014 and 1013) and P. menziesii (at site 1009), for a total of 268 stem discs. Stem discs were collected at stem breast height $(1.3 \mathrm{~m})$ during a thinning aimed at reducing competition performed in winter 2012. The diameter at breast height (DBH) of the sampled trees was similar or slightly smaller than DBH of all the standing trees in 2012 and thus represents the growth of co-dominant trees (Table 2).

\subsection{Tree-ring width measurements and ring chronology}

133 The selected stem discs were oven-dried to avoid decay and then polished with sandpaper. A flatbed distortion-free scanner (Epson, Expression 11000XL) was used to collect digital images of the disc surfaces. The widths of the annual growth rings of four to five radii per disc were measured on the digital image using the WinDendro software (Regent Instruments Canada Inc., 2012). Each individual time-series (radius) was visually cross-dated, and dating was verified using the COFECHA software (Holmes, 1983). Individual time 
series were then detrended using a 10-year cubic smoothing spline to only preserve high-frequency climatic information (Cook and Peters, 1981). Site and species chronologies were built using a biweight robust mean of the detrended tree-ring width indexes (Cook and Kariukstis, 1990). The strength of the common signal among radii was quantified as the mean inter-trees correlation (Rbar) and the expressed population signal (EPS) from the detrended chronologies (Wigley et al., 1984). All calculations were performed with the “dplR” package within the R environment (Bunn, 2008).

\subsection{Growth responses to climate}

For each site and species, growth-climate relationships were assessed with bootstrapped principal component regression (PCR) analyses (Biondi and Waikul, 2004) using the growth chronologies as dependent variables and the monthly climate data as independent variables. Bootstrapped correlation coefficients were calculated with the R package bootRes (Zang and Biondi, 2013) including climate variables from June of the previous year to September of the current year. The statistical significance of the response coefficients was assessed by calculating the $95 \%$ confidence levels based on 1000 random samplings with replacement. As climate data we used the monthly mean temperature $(T m)$ and a monthly drought index $(D I)$ estimated as monthly precipitation minus monthly potential evapotranspiration. Estimates of monthly temperature, precipitation and potential evapotranspiration at each site were obtained from the $0.5^{\circ}$ gridded estimates of CRU TS v.3.22 (Harris et al., 2014). These estimates are based on data from 7-107 stations depending on site and year. Despite daily climatic data are more appropriate to assess droughts which are not confined within monthly periods, we decided to work with monthly resolution data to reduce the number of explanatory climatic parameters to be included into the model (see below).

To evaluate growth resilience in response to drought, we applied superposed epoch analysis (SEA, Lough and Fritts, 1987). SEA analysis tests the significance of a mean tree growth response to certain events (such as drought episodes) by calculating the departures from the mean tree-ring index values of specified events 
and/or subsequent years from the years prior to the event using a bootstrap resampling. In our case we used 1000 random sets to test the significance $(P<0.05)$ of the growth reduction in comparison to the 3 years prior to selected drought events. As drought events we selected the three years (2006, 1992 and 1976) within the study period (1967-2012) that had the lowest June and July drought indices (herein DI67). DI67 for these years were lower than $-175 \mathrm{~mm}$, while the overall site averages ranged between $-47 \mathrm{~mm}$ and $-88 \mathrm{~mm}$. Field observations reported that these drought episodes impacted the forests in Denmark with occurrence of dieback, shoot- and leaf shed (Fog, 1977; Larsen et al., 1993; Thomsen, 2008; Yde-Andersen, 1977).

Additionally, we calculated three different resilience components according to Lloret et al. (2011): Resistance: $R t=D r / P r e D r$, i.e. the ratio between growth during drought and the growth prior to drought; Resilience: $R s=$ PostDr/PreDr, i.e. the after-drought ability to reach performance levels observed prior to drought; and the Relative resilience: $R R s=(P o s t D r-D r) / P r e D r$, i.e the resilience weighted by the impact experienced during drought. These components were calculated based on the individual tree-ring index $(R W I)$ for the drought year $(D r)$, for the average of the three years before (PreDr) and after (PostDr) the drought.

To test for differences in drought-induced growth reductions (from SEA) and $R t, R s$ and $R R s$ among species and sites we applied a linear model with species and site as class variables. Tukey tests were applied for pairwise comparisons in case of overall significant difference between species. For the analysis we used the MIXED procedure in the statistical software SAS (SAS Institute Inc. 2015).

\subsection{Prediction of future growth}

For the growth projections into future climate scenarios we used multiple regression models based on monthly climatic parameters to achieve the best fits to the ring-width indices of each species. The model was defined as:

$$
R W I_{i j}=\mu+\beta_{1} X_{1 j}+\beta_{2} X_{2 j}+\ldots . . \beta_{n} X_{n j}+e_{i j}
$$


Where $R W I_{i j}$ is the mean tree-ring index in field trial $i(\mathrm{i}=1,2 \ldots 6)$ and year $j, \mu$ is the general mean, $X_{1 j} \ldots$ $X_{n j}$ are climate variables 1 to $\mathrm{n}$ in year $j, \beta_{i} \ldots \beta_{n}$ are regression coefficients for climate variables 1 to $n$, and $e_{i j}$ is the residual. As climatic variables we used monthly or multi-months averages of temperatures $(\mathrm{Tm})$ and cumulated aridity indices $(m t)$ observed over the period 1972-2012. The aridity index $m t$ was calculated as $P /(T m+10)$, where $P$ is the monthly precipitation and $T m$ the monthly average temperature in degree Celsius (De Martonne, 1926). Due to the large number of explanatory variables, we performed a preselection of climate parameters based on climate-growth Pearson correlations $(P<0.05)$. The final selection of climate variables was performed for each tree species using the MIXED procedure in SAS (SAS Institute Inc. 2015) with a first-order autoregressive structure between years within sites.

The Akaike's information criterion (AIC; Akaike, 1974) was used to select among models (Burnham and Anderson, 2002). Only statistical significant variables were retained in the model. The above model was supported by estimation of variance inflation factors (VIF) using the REG procedure of SAS (Chatterjee and Hadi, 2006).

As future climatic scenario we used the Global Climate Model (AOGCMs) of the CMIP5 multi-model (corresponding to the 5th IPCC Assessment Report (2013)) that provides projections for monthly climatic data based on the emission scenarios (RCP4.5). This scenario projects an average global warming increase of $+1.4^{\circ} \mathrm{C}( \pm 0.5)$ by the $2050 \mathrm{~s}$ and $+1.8^{\circ} \mathrm{C}( \pm 0.7)$ by the 2080 s in comparison to the period $1991-2009$. Future climatic data were generated with the ClimateEU v4.63 software package for three time windows (20112040; 2041-2070 and 2071-2100), as available at http://tinyurl.com/ClimateEU. Growth projections were estimated from the final multiple regression model and by use of mean climate estimates for the time 
windows including the reference period 1991-2009. Finally, the predicted growth for the three time windows

210 was compared with the reference period, i.e.

$211 \quad F D(\%)=\frac{\left(P D_{f}-P D_{c}\right) \times 100}{P D_{c}}$

Where $F D(\%)$ is the percentage change in growth for the three periods 2011-2040, 2041-2070 and 20712100 compared with the reference period 1991-2009, $P D_{f}$ is the predicted growth in the future three time windows; $P D_{c}$ is the predicted growth for the reference period (1991-2009) applying the regression model.

\section{Results}

\subsection{Characteristics of sampled trees and tree-ring chronologies}

Although being the results of a thinning, the sizes of sampled trees (tree height and mean diameter) were similar to the remaining trees (Table 2), meaning that the growth of the sampled trees were similar to the codominant trees at the sites. Depending on species and site, the mean diameter at breast height (DBH) of the sampled trees ranged from 11.8 to $43.1 \mathrm{~cm}$. In general the slowest growth was observed at the sites 1013 and 1014, while the species at other sites, with few exceptions, were growing faster (Fig. 2). Over the period 1975 to 2012, the mean annual radial growth ranged from 1.26 to $4.46 \mathrm{~mm}$ (Table 2). Conifers grew faster than broadleaved trees. Q. robur showed the slowest diameter growth and A. grandis the fastest. A. grandis displayed the highest growth variability among sites, ranging from 2.19 to $4.46 \mathrm{~mm} / \mathrm{year}$, while the smallest was observed for $Q$. robur (1.26 to $2.74 \mathrm{~mm} /$ year).

When considering the growth pattern, trees within the same species were synchronous across all sites since all chronologies reached the critical level of EPS $\geq 0.85$ and the average Rbar is 0.42 (Table 2). The highest agreement was found for the site 1014, with L. kaempferi and Q. robur having the highest common signals $(\mathrm{Rbar}=0.66)$. 


\subsection{Climate-growth relationships}

233 The climate-growth relationships highlighted the importance of June, July and August $D I$ for the growth of all species, except for $Q$. robur (Fig. 3a). $R W I$ correlated significantly and positively $(P<0.05)$ with June, July and/or August $D I$ in at least one of the sites for all the other species (one site for F. sylvatica and up to five for L. kaempferi). This means that tree growth benefitted from high water availability during summer, or absence of summer drought stress. However, no clear pattern in correlations emerged with regard to the site soil water storage capacity (i.e. site 1013 and 1014 with poor growing conditions and lower growth rate did not always show stronger climate relationships).

Other important patterns were emerging from the correlations with the mean monthly temperatures $(\mathrm{Tm})$, (Fig. 3b). Significant correlations of $R W I$ with $T m$ of previous fall and current spring were in some cases supported by across site tendencies. Three conifers ( $P$. abies, A. alba and A. grandis), showed consistent tendencies to a negative correlation of $R W I$ with previous-year September and October $T m$, while P. abies and A. alba positively responded to previous December Tm and P. menziesii and A grandis to February and/or March $T m$. In contrast, the $R W I$ of the broadleaved species significantly profited from warm temperatures at the beginning of the growing season (April for F. sylvatica and May for Q. robur) and to previous-year October (Q. robur).

Significant correlations of $R W I$ with $D I$ and $T m$ related to a single species and/or site were also observed for other months. $R W I$ was significantly correlated with $D I$ in previous year June and August for L. kaempferi, previous August for Q. robur, and previous September or October for P. abies, A. grandis, P. menziesii, and 251 A. alba. As regard the responses to $T m, Q$. robur responded negatively to high $T m$ in September, $L$. 252 kaempferi to previous July $T m$ and $P$. abies to current June $T m$.

\subsection{Species-specific resilience to drought}

255 The results from the Superposed Epoch Analysis (SEA) assessing the magnitude and the significance of the 
growth departures during and following severe drought events are shown in Figure 4. The analyses showed 257 significant negative growth departures during the drought year for all the species. For example, P. abies and A. grandis showed significant growth departures at five and four out of six sites, respectively. Except for $L$. kaempferi, which at one site still showed a significant growth reduction persisting also in the subsequent year at site 1013, all the other species were able to recover without any significant departure. The analyses of the components of resilience indicated that the species were not different as regard the resistance to drought $(R t)$ and the relative resilience $(R R s)$ (Table 3). However, Q. robur, F. sylvatica, $A$. $a l b a$, and $P$. menziesii showed significantly higher resilience than P. abies, P. sitchensis, A. grandis and $L$. kaempferi (Table 3). The comparison of the RWI departure in the drought years $(1976,1992$ and 2006) showed a site effect on the response (Table 4), as the sites 1014 and 1008 had a statistically larger growth reduction.

\subsection{Prediction of future growth among tree species}

The $95 \%$ confidence interval of the average temperature $T m$ and cumulated aridity index $m t$ for the period 1972-2012, which was used for the development of the climate response models, were within the range of future predicted mean temperature and cumulated aridity index estimates (Table 5). The final multiple regression models for the different species in general included similar climate variables as emerged from the climate-growth relationships. The main difference is related to the model used for P. menziesii, which included a negative effect of previous late summer and early autumn $\mathrm{Tm}$ and an effect of previous year cumulated $m t$ for May and June, which was not recognized from the by site correlation analysis (Fig.3b). The climate response model for $A$. alba did not include previous-autumn temperature in contrast to the results from the by site correlation analysis (Fig. $3 b$ ). Additionally, the prediction model of $A$. alba suggest a negative effect of previous-year cumulated aridity index from March-July (Table 5). The inclusion of the site-by-climate effects into the model did not improve the final multiple regression models (according to the 
AIC criterion, data was not shown), thus indicating that the site conditions were not significantly improving 281 the model for any species.

282 The multiple regression models applied to the RCP4.5 climate scenarios predicts that the growth $(R W I)$ of $P$. abies, L. kaempferi, A. grandis and F. sylvatica will decrease moderately by 4-8\% from 2011-2040, and more strongly by $10-16 \%$ from 2071-2100. The growth of P. menziesii, A. alba and P. sitchensis will stay unchanged, while the growth of $Q$. robur is projected to increase moderately $(+12 \%$ by $2071-2100)$ due to higher spring and autumn temperatures (Table 5).

Summer drought (characterized by low aridity index indices and high temperatures) will negatively affect the growth of all conifers except for P. menziesii (Table 5). High temperatures of the previous late summer and/or autumn will result in more severe growth reductions for P. abies, A. grandis and P. menziesii by $9 \%$, $8 \%$ and $7 \%$ in $2071-2100$, respectively (Table 5 ).

\section{Discussion}

\subsection{Opportunity offered by the research setting}

Previous studies have shown the usefulness of common garden experiments to assess survival rates and reconstruct species responses to past environmental conditions (e.g. Eilmann et al., 2014; Eilmann and Rigling, 2012; Lévesque et al., 2014). This study, based on a common garden experiment established in the mid 60ies, enabled us to compare the growth responses of forestry-relevant species growing at a range of sites over almost the last 4 decades. Thanks to this outstanding research setting we were able to compare species reactions to extreme climatic years (e.g. the summer drought events of 2006, 1992 and 1976) occurring when trees were already in a more advanced stage of maturity. Experimental settings rarely permit studies of stress reactions of mature trees ( $>30$ years old). Moreover, the design of our common garden trials characterized by several sites distributed over the Danish territory (Holmsgaard and Bang, 1977) allowed us to study the variability of the responses in relation to the site conditions. 
A limitation is that our growth models are solely based on relationship between growth and climatic variables of a given landrace or provenance. The model did not include the adaptation of tree phenotypic plasticity (e.g. possible modifications of the root/shoot ratio, leaf area index, rate of photosynthesis, xylem anatomical features), which may strongly influence the growth response to future climate change (Grulke, 2010; Rita et al., 2015; Sabaté et al., 2002; Wohlgemuth, 2015). This means also that our growth forecast does not include the effect of other environmental factors, as for example the impact of increasing atmospheric $\mathrm{CO}_{2}$ concentrations. Indeed, elevated concentrations of $\mathrm{CO}_{2}$ are expected to increase photosynthetic rates and water use efficiency, which may offset drought stress of trees (Ainsworth and Rogers, 2007; Picon et al., 1996). Furthermore, the growth models do not consider that the future climate will also encompass more extreme drought events that possibly will be beyond the drought events experienced in the years from 1972-2012 covered by the growth models in this study.

\subsection{Growth performance of species}

Our results indicated that the considered species clearly diverged in terms of annual productivity and sensitivity to climate, but that the different site conditions were not modifying the main patterns of climate responses observed among the species. In particular, the six conifer species grew faster than the broadleaved species, with the non-native $A$. grandis showing about 2 to 2.5 fold faster radial growth than the slow growing Q. robur (Table 2). Despite the differences in growing conditions among the field trials, with two sites which are clearly less fertile (i.e. 1013 and 1014), the ranking of productivity among the species did not change substantially (Fig. 2), although Callesen et al. (2006) in contrast to the conifers found a positive total growth volume of $Q$. robur and $F$. sylvatica to soil nutrient status, soil water storage capacity and mean annual temperature, including also thinning volumes. Furthermore, correlations between growth and $D I$ in spring and summer (Fig. 3a) and the growth departures for the dry years were not stronger at sites with lower soil water storage capacity as e.g. 1013 (Table 1 and 4). Similarly, the multiple regression models did not 
show significant interaction between sites and climate for all investigated species. We therefore interpret this lack of site-specific responses either as an indication that site conditions were not as large among the sites to determine differing responses to drought, or that other factors as e.g. root depths, groundwater table and nutrient differences among sites have masked these potential responses.

\subsection{Species specific sensitivity to climate}

The observed differences in strength and seasonality of the growth responses among species obtained from the multiple regressive model resulted in large dissimilarities when projecting species growth performance into a future climate scenario characterized by warmer annual temperatures $\left(+1.8^{\circ} \mathrm{C} \pm 0.7\right)$ and dryer summer $\left(-0.52 \mathrm{~mm}^{\circ} \mathrm{C}^{-1} \pm 0.20\right)$ in comparison to the period 1991-2009 (Fig. 1). In particular, our model forecasts that by the year 2080 s the slow-growing $Q$. robur will increase the growth by $12 \%$, while in contrast $L$. kaempferi and P. abies will reduce growth by $15-16 \%$ (Table 5). The other species considered are within this range, but towards a growth reduction. Generally, the results from the multiple regression models are in agreement with the climate-growth correlations from the bootstrapping, but with few differences, which reflect the uncertainty of the models. In this context, $Q$. robur, the only species expected to increase growth, is also the species that showed a lack of significant relationships with drought related climate variables. The forecasted increase in growth is mainly due to the benefits from the positive response to previous-autumn and currentspring warming combined with relative less sensitivity to summer drought (Fig. 3) and better resilience to drought events (Table 3), which might be due to a deep tap root system (Čermák and Fér, 2007).

These observations are consistent with studies on Quercus petraea, which distribution range extensively overlaps with $Q$. robur. It has been found that the tree-ring width of $Q$. petraea is also positively affected by previous October-November and current year May temperatures (Lebourgeois et al., 2004). The importance of the previous autumn conditions for carbon storage to sustain next year growth is stressed by the finding that $Q$. petraea stem growth started 10 days before bud burst (Barbaroux and Bréda, 2002) and about 30\% of 
the total annual stem increment (mainly earlywood formation) is added before bud burst in ring-porous species (Bréda and Granier, 1996; Hinckley and Lassoie, 1981) and hence before the soil water content is reduced during the growing season (Barbaroux and Bréda, 2002). Moreover, an early and warm spring enhances both photosynthesis and the use of the carbon reserve (Corcuera et al., 2005), explaining the positive response to spring temperatures. On the other hand, it has also been reported that Q. petraea during drought maintains a consistently better water status than F. sylvatica due to its ability to access water in deep soil layers (Leuzinger et al., 2005). This can be explained by the fact that at soil depth between 50 and 90 $\mathrm{cm}, F$. sylvatica has lower density of coarse roots and higher fine root mortality during drought than $Q$. petraea (Leuschner et al., 2001a; 2001b). This growth behaviour also suggests that $Q$. petraea distributes the growth effort over the full growing season, reducing the impact of the summer when growth conditions in dry sensitive environments are usually unfavourable. It is therefore not surprising that the genus, in particularly dry environments as in the Rhone Valley in Switzerland, is out-competing Pinus sylvestris L. (e.g., Weber et al., 2008, 2007). Both Q. petraea and Q. robur displayed a high degree of tolerance to drought due to deep-root system, high transpiration and stomatal conductance under drought (Epron and Dreyer, 1993). However, Q. petraea might be more competitive than $Q$. robur with higher leaf specific conductivity and intrinsic water-use efficiency than Q. robur after severe drought (Cochard et al., 1992; Epron and Dreyer, 1993).

Contrastingly, the growth of $P$. abies, P. sitchensis, A. alba, A. grandis and L. kaempferi, F. sylvatica and $P$. menziesii were observed to be significantly reduced during dry years and/or under high summer temperatures (Fig. 3). These observations confirm results from numerous other studies showing their general sensitivity to drought (e.g. Bolte et al., 2010; Bošel'a et al., 2014; Bouriaud and Popa, 2009; Desplanque et al., 1999; Eilmann and Rigling, 2012; Feliksik and Wilczyński, 2008; Lebourgeois et al., 2010; Lévesque et al., 2014; Tegel et al., 2014; Zang et al., 2014). Among this group of species, L. kaempferi and P. abies are expected to have the largest growth reduction, since they are particularly sensitive to drought. Although observations of 
species root behaviour at the sites are missing, knowledge that both species are generally shallow-rooted (Puhe 2003; Sakai et al., 2007) makes us speculate that these two species either have a wood properties more prone to hydraulic failures (Bréda et al., 2006; Choat et al., 2012; Cochard et al., 1992) or are more sensitive to soil water deficits than other deep-rooted species (Lévesque et al., 2013). Indeed, L. kaempferi was, among the six conifers, the species with the lowest growth resilience to drought (Table 3) and with a lagged negative response to previous summer temperature. The previous-year summer temperature could potentially influence bud initiation, fruit set, and respiration and thus reduce carbon reserves for next year's growth (Oleksyn and Fritts, 1991). Thus, L. kaempferi seems not only less resilient, but also more liable to the negative effect of climate warming. Similarly $A$. grandis showed significant reductions in the dry years, but a deeper root system might make it more tolerant to drought than P. abies (Xu et al., 1997). In this case however, the expected reduced growth is exacerbated by the negative responses to warm temperatures in the previous autumn and/or current summer on $P$. abies and A. grandis. The negative effects of previous warm September-October found in this study could be the effect of high evapotranspiration combined with poor soil water availability at the end of the growing season. As there is no correlation with drought at this time of the season, an alternative interpretation could be a negative carbon balance due to high respiration as observed in France (Lebourgeois et al., 2010) and suggested by Bouriaud and Popa (2009).

Finally, the radial growth of $A$. alba, $P$. sitchensis and $P$. menziesii were less impacted by future climate variability than the other coniferous species. Except for P. menziesii, which still show some negative response to previous year temperature, these species appeared insensitive to both previous year temperature and less affected to current summer drought and warm temperature. In the case of $P$. menziesii, this might be related to a higher proportion of latewood-like cells which are resistant to drought-induced cavitation, but still sufficient hydraulic conductive (Domec and Gartner, 2002; Huang et al., in preparation; Martinez-Meier et al., 2008). This insensitivity might also be due to its deeper root systems. In the case of $P$. sitchensis, the growth prediction model is possibly underestimating the importance of the summer drought since the 
climate-growth correlations and the SEA analysis have indicated certain sensitivity to drought.

Even though $A$. alba showed a significant negative effect from previous autumn temperature, warm winter can initiate its winter photosynthesis and improve carbohydrate storage for the following growing season (Bouriaud and Popa, 2009; Guehl et al., 1985; Lebourgeois, 2007; Lebourgeois et al., 2010; Van Der Maaten-Theunissen et al., 2013). As a deep taproot species which allows $A$. alba trees reaching deeper water resources it will be more tolerant to water deficit than sensitive conifer species (Larcher, 1995). In addition, P. menziesii displayed a positive response to years with a warm and dry spring that helped to compensate the negative effect of warming during other times of the growing season. This is a positive effect that has also been observed in a stand in Western Pomerania (Feliksik and Wilczyński, 2009).

\section{Conclusions}

We assessed the growth responses of six conifers and two broadleaves to climatic variability and severe drought events in six Danish field trials. The growth rate was diverse between sites with contrasting soil types, but the climatic response was not obviously different among field trials. The responses to climatic variability and drought were not uniform and varied among species in relation to their growth behaviour. The model predictions indicate that $Q$. robur is the only species which will benefit from the predicted climate changes in Denmark with increased temperatures and unchanged or slightly reduced precipitation in the growing season. L. kaempferi and P. abies were the most sensitive species to summer drought events due to their low resilience and high sensitivity to previous season warmth and current season drought. This study not only provides important observations on past growth, but also demonstrates that old common gardens can be a valuable tool for addressing forest management questions on species portfolios that match future climates. 


\section{Acknowledgements}

423 This study is funded by the China Scholarship Council (CSC, No.201306910037), the Glud foundation 424 (Gluds Legat) and the Villum Foundation. This study profited from discussions within the framework of the 425 COST Action STReESS (COST-FP1106). We are further grateful for valuable comments, data on the growth 426 and thinning regime in the common garden field trials provided by Lisbeth Garbrecht Thygesen and Bruno 427 Bilde Jørgensen. 


\section{References}

Ainsworth, E.A., Rogers, A., 2007. The response of photosynthesis and stomatal conductance to rising $\left[\mathrm{CO}_{2}\right]$ : mechanisms and environmental interactions. Plant, Cell Environ. 30, 258-270. doi:10.1111/j.13653040.2007.01641.x

Akaike, H., 1974. A new look at the statistical model identification. IEEE Trans. Autom. Control 19, 716-723. doi:10.1109/TAC.1974.1100705

Allen, C.D., Macalady, A.K., Chenchouni, H., Bachelet, D., McDowell, N., Vennetier, M., Kitzberger, T., Rigling, A., Breshears, D.D., Hogg, E.H. (Ted), Gonzalez, P., Fensham, R., Zhang, Z., Castro, J., Demidova, N., Lim, J.H., Allard, G., Running, S.W., Semerci, A., Cobb, N., 2010. A global overview of drought and heat-induced tree mortality reveals emerging climate change risks for forests. For. Ecol. Manage. 259, 660-684. doi:10.1016/j.foreco.2009.09.001

Anderegg, W.R.L., Hicke, J.A., Fisher, R.A., Allen, C.D., Aukema, J., Bentz, B., Hood, S., Lichstein, J.W., Macalady, A.K., McDowell, N., Pan, Y., Raffa, K., Sala, A., Shaw, J.D., Stephenson, N.L., Tague, C., Zeppel, M., 2015. Tree mortality from drought, insects, and their interactions in a changing climate. New Phytol. 208, 674-683. doi:10.1111/nph.13477

Barbaroux, C., Bréda, N., 2002. Contrasting distribution and seasonal dynamics of carbohydrate reserves in stem wood of adult ring-porous sessile oak and diffuse-porous beech trees. Tree Physiol. 22, 1201-1210. doi:10.1093/treephys/22.17.1201

Biondi, F., Waikul, K., 2004. DENDROCLIM2002: A C++ program for statistical calibration of climate signals in treering chronologies. Comput. Geosci. 30, 303-311. doi:10.1016/j.cageo.2003.11.004

Bolte, A., Hilbrig, L., Grundmann, B., Kampf, F., Brunet, J., Roloff, A., 2010. Climate change impacts on stand structure and competitive interactions in a southern Swedish spruce-beech forest. Eur. J. For. Res. 129, $261-276$. doi:10.1007/s10342-009-0323-1

Bošel'a, M., Sedmák, R., Sedmáková, D., Marušák, R., Kulla, L., 2014. Temporal shifts of climate-growth relationships of Norway spruce as an indicator of health decline in the Beskids, Slovakia. For. Ecol. Manage. 325, $108-117$. doi:10.1016/j.foreco.2014.03.055

Bouriaud, O., Popa, I., 2009. Comparative dendroclimatic study of Scots pine, Norway spruce, and silver fir in the Vrancea Range, Eastern Carpathian Mountains. Trees - Struct. Funct. 23, 95-106. doi:10.1007/s00468-008-0258Z

Bréda, N., Granier, A., 1996. Intra- and interannual variations of transpiration, leaf area index and radial growth of a sessile oak stand (Quercus petraea). Ann. For. Sci. 53, 521-536. doi:10.1051/forest:19960232

Bréda, N., Huc, R., Granier, A., Dreyer, E., 2006. Temperate forest trees and stands under severe drought: a review of ecophysiological responses, adaptation processes and long-term consequences. Ann. For. Sci. 63, 625-644. doi: 10.1051/forest:2006042 
Bunn, A.G., 2008. A dendrochronology program library in R (dplR). Dendrochronologia 26, 115-124. doi:10.1016/j.dendro.2008.01.002

Burnham, K.P., Anderson, D.R., 2002. Model Selection and Multi-Model inference: A Practical Information- Theoretic Approach. Springer- Verlag, Heidelberg, 60-74 pp.

Callesen, I., 2003. Transfer functions for carbon sequestration, nitrogen retention, and nutrient release capability in forest soils based on soil texture classification. PhD Thesis, Skov \& Landskab, University of Copenhagen.

Callesen, I., Raulund-Rasmussen, K., 2004. Base cation, aluminium, and phosphorus release potential in Danish forest soils. J. Plant Nut. Soil Sci. 167: 169-176. doi: 10.1002/jpln.200321202

Callesen, I., Raulund-Rasmussen, K., Jørgensen, B.B., and Kvist-Johannsen, V. 2006. Growth of beech, oak, and four conifer tree species along a soil fertility gradient. Balt. For. 12: 14-23.

Čermák, P., Fér, F., 2007. Root systems of forest tree species and their soil-conservation functions on the Krušné hory Mts. slopes disturbed by mining. J. For. Sci. 53: 561-566.

Chatterjee, S., Hadi, A.S., 2006. Analysis of Collinear Data, in Regression Analysis by Example, Fourth Edition, John Wiley \& Sons, Inc., Hoboken, NJ, USA. doi: 10.1002/0470055464.ch9

Choat, B., Jansen, S., Brodribb T.J., Cochard, H., Delzon, S., Bhaskar, R., Bucci, S.J., Field, T.S., Gleason, S.M., Hacke, U.G., Jacobsen, A.L., Lens, F., Maherali, H., Martínez-Vilalta, J., Mayr, S., Mencuccini, M., Mitchell, P.J., Nardini, A., Pittermann, J., Pratt, R.B., Sperry, J.S., Westoby, M., Wright, I.J., Zanne, A.E., 2012. Global convergence in the vulnerability of forests to drought. Nature 491, 752-756. doi:10.1038/nature11688

Cochard, H., Bréda, N., Granier, A., Aussenac, G., 1992. Vulnerability to air embolism of three European oak species (Quercus petraea (Matt) Liebl, $Q$ pubescens Willd, $Q$ robur L). Ann. For. Sci. 49, 225-233. doi:10.1051/forest:19920302

Cook, E.R., Kairiukstis, L. (Eds.), 1990. Methods of Dendrochronology: Applications in the Environmental Sciences. Kulwer, The Netherlands.

Cook, E.R., Peters, K., 1981. The smoothing spline: a new approach to standardizing forest interior tree-ring width series for dendroclimatic studies. Tree-Ring Bull. 41, 45-53.

Corcuera, L., Morales, F., Abadía, A, Gil-Pelegrín, E., 2005. Seasonal changes in photosynthesis and photoprotection in a Quercus ilex subsp. ballota woodland located in its upper altitudinal extreme in the Iberian Peninsula. Tree Physiol. 25, 599-608. doi:10.1093/treephys/25.5.599

Dai, A., 2013. Increasing drought under global warming in observations and models. Nat. Clim. Chang. 3, 52-58. doi:10.1038/nclimate1633

De Martonne E., 1926. Une nouvelle fonction climatologique: L'indice d'aridité. La Meteorologie, 449-458.

Desplanque, C., Rolland, C., Schweingruber, F.H., 1999. Influence of species and abiotic factors on extreme tree ring modulation: Picea abies and Abies alba in Tarentaise and Maurienne (French Alps). Trees - Struct. Funct. 13, 218-227. doi:10.1007/s004680050236

Domec, J-C., Gartner, B.L., 2002. How do water transport and water storage differ in coniferous earlywood and 
latewood? J. Exp. Bot. 53, 2369-2379. doi:10.1093/jxb/erf100

Eilmann, B., Rigling, A., 2012. Tree-growth analyses to estimate tree species' drought tolerance. Tree Physiol. 32, 178187. doi:10.1093/treephys/tps004

Eilmann, B., Sterck, F., Wegner, L., De Vries, S.M.G., Von Arx, G., Mohren, G.M.J., Den Ouden, J., Sass-Klaassen, U., 2014. Wood structural differences between northern and southern beech provenances growing at a moderate site. Tree Physiol. 34, 882-893. doi:10.1093/treephys/tpu069

Epron, D., Dreyer, E., 1993. Long-term effects of drought on photosynthesis of adult oak trees [Quercus petraea (Matt.) Liebl. and Quercus robur L.] in a natural stand. New Phytol. 125, 381-389.

Feliksik, E., Wilczyński, S., 2009. The effect of climate on tree-ring chronologies of native and nonnative tree species growing under homogenous site conditions. Geochronometria 33, 49-57. doi:10.2478/v10003-009-0006-4

Feliksik, E., Wilczyński, S., 2008. Tree-ring chronology as a source of information on susceptibility of Sitka spruce to climatic conditions of Pomerania (Northern Poland). Geochronometria 30, 79-82. doi:10.2478/v10003-008-00020

Field, C.B., Barros, V.R., Dokken, D.J., Mach, K.J., Mastrandrea, M.D., Bilir, T.E., Chatterjee, M., Ebi, K.L., Estrada, Y.O., Genova, R.C., Girma, B., Kissel, E.S., Levy, A.N., MacCracken, S., Mastrandrea, P.R., White, L.L., 2014. IPCC, 2014: Climate Change 2014: Impacts, Adaptation, and Vulnerability. Part A: Global and Sectoral Aspects. Contribution of Working Group II to the Fifth Assessment Report of the Intergovernmental Panel on Climate Change. Cambridge University Press, Cambridge, United Kingdom and New York, NY, USA, 1132 pp. Fog, O., 1977. Tørkeskader. Skoven 9, 248.

Forest Europe, UNECE, and FAO (2015). "State of Europe's forests 2015”, in Ministerial Conference on the Protection of Forests in Europe (Madrid), 314 pp.

Gaylord, M.L., Kolb, T.E., Pockman, W.T., Plaut, J.A, Yepez, E.A, Macalady, A.K., Pangle, R.E., Mcdowell, N.G., 2013. Drought predisposes piñon- juniper woodlands to insect attacks and mortality. New Phytol. 567-578. doi:10.1111/nph.12174

Grulke, N.E., 2010. Plasticity in physiological traits in conifers: Implications for response to climate change in the western U.S. Environ. Pollut. 158, 2032-2042. doi:10.1016/j.envpol.2009.12.010

Guehl, J.M., Clerc, B., Desjeunes, J.M., 1985. Etude comparée des potentialités hivernales d'assimilation carbonée de trois conifères de la zone tempérée (Pseudotsuga menziesii Mirb., Abies alba Mill. et Picea excelsa Link.). Ann. For. Sci. 42, 23-38.

Hanewinkel, M., Cullmann, D.A., Schelhaas, M., Nabuurs, G., Zimmermann, N.E., 2013. Climate change may cause severe loss in the economic value of European forest land. Nat. Clim. Chang. 3, $203-207$. doi:10.1038/nclimate1687

Hansen, K., Bastrup-Birk, A., Bille-Hansen, J., Vesterdal, L., Gundersen, P., 2003. Chapter 6. Jordbundens rolle i skove [in Danish]. In: Hansen, K (ed.) (2003): Næringsstofkredsløb i skove - Ionbalanceprojektet - Forest and Landscape Research, No 33-2003. ISBN 97-7903-156-0. Kandrups Bogtrykkeri. Hørsholm, Denmark. 
Harris, I., Jones, P.D., Osborn, T.J., Lister, D.H., 2014. Updated high-resolution grids of monthly climatic observations - the CRU TS3.10 Dataset. Int. J. Climatol. 34, 623-642. doi:10.1002/joc.3711

Hinckley, T.M., Lassoie, J.P., 1981. Radial growth in conifers and deciduous trees: a comparison. Proc. IUFRO Conf. Physiol. Asp. For. Ecol. Mitteil. d, 17-56.

Holmes, R.L., 1983. Computer-assisted quality control in tree-ring dating and measurement. Tree-ring Bull. 43, 69-78.

Holmsgaard, E., Bang, C., 1977. Et træartsforsøg med nåletræer, bøg og eg; de første 10 år [A species trial with conifers, beech and oak; the first 10 years]. Forstl. Forsøgsvæs. Dan 35: 159-196 (In Danish).

IPCC, 2013. Climate Change 2013: The Physical Science Basis. Working Group I: Contribution to the Fifth Assessment Report of the Intergovernmental Panel on Climate Change. Cambridge University Press, Cambridge, United Kingdom and New York, NY, USA, 1535 pp. doi:10.1017/CBO9781107415324

Jactel, H., Petit, J., Desprez-Loustau, M.L., Delzon, S., Piou, D., Battisti, A., Koricheva, J., 2012. Drought effects on damage by forest insects and pathogens: a meta-analysis. Glob. Chang. Biol. 18, 267-276. doi:10.1111/j.13652486.2011.02512.x

Kirilenko, A.P., Sedjo, R.A., 2007. Climate change impacts on forestry. Proc. Natl. Acad. Sci. U.S.A. 104, $19697-702$. doi:10.1073/pnas.0701424104

Kjellström, E., Nikulin, G., Hansson, U., Strandberg, G., Ullerstig, A., 2011. 21st century changes in the European climate: uncertainties derived from an ensemble of regional climate model simulations. Tellus Ser. A Dyn. Meteorol. Oceanogr. 63A, 24-40. doi:10.1111/j.1600-0870.2010.00475.x

Larcher, W., 1995. Physiological plant ecology. Springer, Berlin, DE.

Larsen, J.B., Koch, J., Münster-Swendsen, M., Saxe, H., 1993. Skovenes sundhed på udvalgte distrikter i efteråret 1992. Skoven 25, 261-264.

Lebourgeois, F., 2007. Climatic signal in annual growth variation of silver fir (Abies alba Mill.) and spruce (Picea abies Karst.) from the French Permanent Plot Network (RENECOFOR). Ann. For. Sci. 64, $333-343$. doi:10.1051/forest:2007010

Lebourgeois, F., Cousseau, G., Ducos, Y., 2004. Climate-tree-growth relationships of Quercus petraea Mill. stand in the Forest of Bercé ("Futaie des Clos", Sarthe, France). Ann. For. Sci. 61, 361-372. doi: 10.1051/forest:2004029

Lebourgeois, F., Rathgeber, C.B.K., Ulrich, E., 2010. Sensitivity of French temperate coniferous forests to climate variability and extreme events (Abies alba, Picea abies and Pinus sylvestris). J. Veg. Sci. 21, 364-376. doi:10.1111/j.1654-1103.2009.01148.x

Leuschner, C., Backes, K., Hertel, D., Schipka, F., Schmitt, U., Terborg, O., Runge, M., 2001a. Drought responses at leaf, stem and fine root levels of competitive Fagus sylvatica L. and Quercus petraea (Matt.) Liebl. trees in dry and wet years. For. Ecol. Manage. 149, 33-46.

Leuschner, C., Hertel, D., Coners, H., Büttner, V., 2001b. Root competition between beech and oak: a hypothesis. Oecologia 126, 276-284. doi:10.1007/s004420000507

Leuzinger, S., Zotz, G., Asshoff, R., Körner, C., 2005. Responses of deciduous forest trees to severe drought in Central 
Europe. Tree Physiol. 25, 641-650. doi:10.1093/treephys/25.6.641

Lévesque, M., Rigling, A., Bugmann, H., Weber, P., Brang, P., 2014. Growth response of five co-occurring conifers to drought across a wide climatic gradient in Central Europe. Agric. For. Meteorol. 197, 1-12. doi:10.1016/j.agrformet.2014.06.001

Lévesque, M., Saurer, M., Siegwolf, R., Eilmann, B., Brang, P., Bugmann, H., Rigling, A., 2013. Drought response of five conifer species under contrasting water availability suggests high vulnerability of Norway spruce and European larch. Glob. Chang. Biol. 19, 3184-3199. doi:10.1111/gcb.12268

Lindner, M., Fitzgerald, J.B., Zimmermann, N.E., Reyer, C., Delzon, S., van der Maaten, E., Schelhaas, M.J., Lasch, P., Eggers, J., van der Maaten-Theunissen, M., Suckow, F., Psomas, A., Poulter, B., Hanewinkel, M., 2014. Climate change and European forests: What do we know, what are the uncertainties, and what are the implications for forest management? J. Environ. Manage. 146, 69-83. doi:10.1016/j.jenvman.2014.07.030

Lloret, F., Keeling, E.G., Sala, A., 2011. Components of tree resilience: effects of successive low-growth episodes in old ponderosa pine forests. Oikos 120, 1909-1920. doi:10.1111/j.1600-0706.2011.19372.x

Lough, J.M., Fritts, H.C., 1987. An assessment of the possible effects of volcanic eruptions on North American climate using tree-ring data, 1602 to 1900 A.D. Clim. Change 10, 219-239. doi:10.1007/BF00143903

Madsen, H.B., Platou, S.W., 1983. Land use planning in Denmark: The use of soil physical data in irrigation planning. Nord. Hydrol. 267-276.

Martinez-Meier, A., Sanchez, L., Pastorino, M., Gallo, L., Rozenberg, P., 2008. What is hot in tree rings? The wood density of surviving Douglas-firs to the 2003 drought and heat wave. For. Ecol. Manage. 256, 837-843. doi:10.1016/j.foreco.2008.05.041

McDowell, N.G., Beerling, D.J., Breshears, D.D., Fisher, R.A., Raffa, K.F., Stitt, M., 2011. The interdependence of mechanisms underlying climate-driven vegetation mortality. Trends Ecol. Evol. 26, 523-532. doi:10.1016/j.tree.2011.06.003

Mette, T., Dolos, K., Meinardus, C., Bräuning, A., Reineking, B., Blaschke, M., Pretzsch, H., Beierkuhnlein, C., Gohlke, A., Wellstein, C., 2013. Climatic turning point for beech and oak under climate change in Central Europe. Ecosphere 4, 145. doi:10.1890/ES13-00115.1

Oleksyn, J., Fritts, H.C., 1991. Influence of climatic factors upon tree rings of Larix decidua and L. deciduax L. kaempferi from Pulawy, Poland. Trees - Struct. Funct. 5, 75-82. doi:10.1007/BF00227488

Olesen, M., Madsen, K.S., Ludwigsen, C.A., Boberg, F., Christensen, T., Cappelen, J., Christensen, O.B., Andersen, K.K., Christensen, J.H., 2014. Fremtidige klimaforandringer i Danmark [Future climate changes in Denmark].

Danmarks Klimacenter, rapport no. 6, Danmarks Meteorologiske Institut.

Orwig, D.A., Abrams, M.D., 1997. Variation in radial growth responses to drought among species, site, and canopy strata. Trees - Struct. Funct. 11, 474-484.

Picon, C., Guehl, J., Aussenac, G., 1996. Growth dynamics, transpiration and water-use efficiency in Quercus robur plants submitted to elevated $\mathrm{CO}_{2}$ and drought. Ann. des Sci. For. 53, 431-446. doi:10.1051/forest:19960225 
Puhe, J., 2003. Growth and development of the root system of Norway spruce (Picea abies) in forest stands-a review. For. Ecol. Manage. 175, 253-237. doi:10.1016/S0378-1127(02)00134-2

Regent Instruments Canada Inc, 2012. WINDENDRO for Tree-ring Analysis. Quebec, Canada.

Reichstein, M., Bahn, M., Ciais, P., Frank, D., Mahecha, M.D., Seneviratne, S.I., Zscheischler, J., Beer, C., Buchmann, N., Frank, D.C., Papale, D., Rammig, A., Smith, P., Thonicke, K., van der Velde, M., Vicca, S., Walz, A., Wattenbach, M., 2013. Climate extremes and the carbon cycle. Nature 500, 287-295. doi:10.1038/nature12350

Rita, A., Cherubini, P., Leonardi, S., Todaro, L., Borghetti, M., 2015. Functional adjustments of xylem anatomy to climatic variability: insights from long-term Ilex aquifolium tree-ring series. Tree Physiol. 35, 817-828. doi:10.1093/treephys/tpv055

Sabaté, S., Gracia, C.A., Sánchez, A., 2002. Likely effects of climate change on growth of Quercus ilex, Pinus halepensis, Pinus pinaster, Pinus sylvestris and Fagus sylvatica forests in the Mediterranean region. For. Ecol. Manage. 162, 23-37. doi:10.1016/S0378-1127(02)00048-8

Sakai, Y., Takahashi, M., Tanaka, N., 2007. Root biomass and distribution of a Picea-Abies stand and a Larix-Betula stand in pumiceous Entisols in Japan. J. For. Res. 12, 120-125. doi:10.1007/s10310-006-0270-3

SAS Institute Inc., 2015. SAS/STAT® 14.1 User's Guide. Cary, NC: SAS Institute Inc.

Sass-Klaassen, U., Fonti, P., Cherubini, P., Gričar, J., Robert, E.M.R., Steppe, K., Bräuning, A., 2016. A tree-centered approach to assess impacts of extreme climatic events on forests. Front. Plant Sci. 7, 1069. doi:10.3389/fpls.2016.01069

Tegel, W., Seim, A., Hakelberg, D., Hoffmann, S., Panev, M., Westphal, T., Büntgen, U., 2014. A recent growth increase of European beech (Fagus sylvatica L.) at its Mediterranean distribution limit contradicts drought stress. Eur. J. For. Res. 133, 61-71. doi:10.1007/s10342-013-0737-7

Thomsen, I. M., 2008. De danske skoves sundhedstilstand. Resultat af overvågningen i 2006. Arbejdsrapport Skov \& Landskab nr. 40-2008. Skov \& Landskab, Københavns Universitet, Hørsholm

Van Der Maaten-Theunissen, M., Kahle, H.P., Van Der Maaten, E., 2013. Drought sensitivity of Norway spruce is higher than that of silver fir along an altitudinal gradient in southwestern Germany. Ann. For. Sci. 70, $185-193$. doi:10.1007/s13595-012-0241-0

Weber, P., Bugmann, H., Fonti, P., Rigling, A., 2008. Using a retrospective dynamic competition index to reconstruct forest succession. For. Ecol. Manage. 254, 96-106. doi:10.1016/j.foreco.2007.07.031

Weber, P., Bugmann, H., Rigling, A., 2007. Radial growth responses to drought of Pinus sylvestris and Quercus pubescens in an inner-Alpine dry valley. J. Veg. Sci. 18, 777-792. doi:10.1111/j.1654-1103.2007.tb02594.x

Wigley, T.M.L., Briffa, K.R., Jones, P.D., 1984. On the average value of correlated time series, with applications in dendroclimatology and hydrometeorology. J. Clim. Appl. Meteorol. 23. 201-213. doi:10.1175/15200450(1984)023<0201:OTAVOC $>2.0 . C O ; 2$

Wohlgemuth, T., 2015. Climate change and tree responses in Central European forests. Ann. For. Sci. 72, $285-287$. doi:10.1007/s13595-015-0474-9 
637 Xu, Y., Röhrig, E., Fölster, H., 1997. Reaction of root systems of grand fir (Abies grandis Lindl.) and Norway spruce

638 (Picea abies Karst.) to seasonal waterlogging. For. Ecol. Manage. 93, 9-19. doi:10.1016/S0378-1127(96)03951-5

639 Yde-Andersen, A., 1977. Tørke og trædød. Skoven 9, 250.

640 Zang, C., Biondi, F., 2013. Dendroclimatic calibration in R: The bootRes package for response and correlation function 641 analysis. Dendrochronologia 31, 68-74. doi:10.1016/j.dendro.2012.08.001

642 Zang, C., Hartl-Meier, C., Dittmar, C., Rothe, A., Menzel, A., 2014. Patterns of drought tolerance in major European 643 temperate forest trees: climatic drivers and levels of variability. Glob. Chang. Biol. 20, 3767-3779.

644 doi: $10.1111 / \mathrm{gcb} .12637$ 
645 Table 1: Characteristics of the selected field trials

\begin{tabular}{|c|c|c|c|c|c|c|c|c|}
\hline Site & Tree species $^{\text {a }}$ & $\begin{array}{l}\text { Lat. } \\
(\mathrm{N})\end{array}$ & $\begin{array}{l}\text { Long. } \\
\text { (E) }\end{array}$ & $\begin{array}{l}\text { Former land use and other specific } \\
\text { site characteristics (from Callesen, } \\
\text { 2003; Callesen and Raulund- } \\
\text { Rasmussen, 2004; Hansen, 2003) } \\
\end{array}$ & $\begin{array}{c}\text { Soil } \\
\text { texture } \\
\text { [class] }\end{array}$ & $\begin{array}{l}\text { Soil water } \\
\text { storage } \\
\text { capacity } \\
{[\mathrm{mm}]} \\
\end{array}$ & $\begin{array}{l}\text { Mean annual } \\
\text { temperature }{ }^{c} \\
{\left[{ }^{\circ} \mathrm{C}\right]}\end{array}$ & $\begin{array}{l}\text { Mean annual } \\
\text { precipitation } \\
{[\mathrm{mm}]}\end{array}$ \\
\hline 1008 & 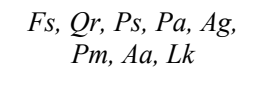 & $56^{\circ} 27^{\prime} 29.0^{\prime \prime}$ & $10^{\circ} 31^{\prime} 54.6^{\prime \prime}$ & $\begin{array}{l}\text { Cropland following heathland, medium- } \\
\text { poor soil nutrient status }\end{array}$ & Sand & 89 & 8.1 & 572 \\
\hline 1009 & $\begin{array}{c}\text { Fs, } Q r, P s, P a, A g \\
A a, L k\end{array}$ & $55^{\circ} 56^{\prime} 23.1^{\prime \prime}$ & $9^{\circ} 12^{\prime} 26.3^{\prime \prime}$ & $\begin{array}{l}\text { Cropland, seasonal high water tables, } \\
\text { very poor soil nutrient status }\end{array}$ & Sand & 84 & 7.7 & 844 \\
\hline 1010 & 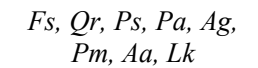 & $55^{\circ} 32^{\prime} 32.6^{\prime \prime}$ & $11^{\circ} 49^{\prime} 37.2^{\prime \prime}$ & Cropland, rich soil nutrient status & $\begin{array}{l}\text { Sandy } \\
\text { loam }\end{array}$ & 95 & 8.3 & 595 \\
\hline 1011 & $\begin{array}{l}\text { Fs, } \begin{array}{l}Q r, P s, P a, A g \\
P m, A a, L k\end{array} \\
\quad\end{array}$ & $55^{\circ} 57^{\prime} 21.3^{\prime \prime}$ & $12^{\circ} 21^{\prime} 14.1^{\prime \prime}$ & Cropland, rich soil nutrient status & $\begin{array}{l}\text { Sandy } \\
\text { loam }\end{array}$ & 122 & 8.2 & 605 \\
\hline 1013 & $\begin{array}{c}\text { Fs, } Q r, P a, A g, P m \\
A a, L k\end{array}$ & $57^{\circ} 11^{\prime} 35.2^{\prime \prime}$ & $9^{\circ} 32^{\prime} 59.3^{\prime \prime}$ & $\begin{array}{c}\text { Sand dunes with Pinus mugo and hay, } \\
\text { seasonal high water tables, very poor } \\
\text { soil nutrient status, possible salt spray } \\
\text { from the sea }\end{array}$ & Sand & 72 & 7.8 & 680 \\
\hline 1014 & $\begin{array}{c}\text { Fs, } Q r, P a, A g, P m \\
A a, L k\end{array}$ & $56^{\circ} 17^{\prime} 32.5^{\prime \prime}$ & $8^{\circ} 25^{\prime} 40.1^{\prime \prime}$ & $\begin{array}{l}\text { Heathland of Calluna vulgaris, very } \\
\text { poor soil nutrient status }\end{array}$ & Sand & 64 & 8.5 & 855 \\
\hline $\begin{array}{l}646 \\
647 \\
648 \\
649\end{array}$ & $\begin{array}{l}{ }^{\mathrm{a}} \text { Fs }=\text { Fagus sylva } \\
=\text { Abies alba, , Lk } \\
{ }^{\mathrm{b}} \text { Available soil wa } \\
{ }^{\mathrm{c}} \text { Average over the }\end{array}$ & $\begin{array}{l}\text { a, Qr }=\text { Quer } \\
\text { Larix kaempf } \\
\text { storage capa } \\
\text { riod } 1961-20\end{array}$ & $\begin{array}{l}\text { S robur, } P s \\
\text { y to a depth }\end{array}$ & $\begin{array}{l}\text { cea sitchensis, } P a=\text { Picea abies, } \mathrm{Ag}= \\
0 \mathrm{~cm} \text { estimated according to the equati }\end{array}$ & $\overline{\text { granc }}$ & $\begin{array}{l}P m=P s e u d \\
\text { and Platou }(1\end{array}$ & a menziesii, $\mathrm{Aa}$ & \\
\hline
\end{tabular}


650 Table 2: Tree characteristics and properties of tree-ring time series

\begin{tabular}{|c|c|c|c|c|c|c|c|c|c|}
\hline Site & Species $^{\mathrm{a}}$ & $\begin{array}{c}\text { Tree/radi } \\
\text { i }\end{array}$ & Period $^{\mathrm{b}}$ & $\begin{array}{l}\text { Tree DBH }{ }^{\mathrm{c}} \\
{[\mathrm{cm}]}\end{array}$ & $\begin{array}{c}\text { Stand DBH }^{\mathrm{d}} \\
{[\mathrm{cm}]}\end{array}$ & $\begin{array}{l}\text { Ring width }^{\mathrm{b}} \\
\text { [mm] }\end{array}$ & $\begin{array}{l}\text { Ring width }^{\mathrm{e}} \\
\text { [mm] }\end{array}$ & Rbar & $\overline{\text { EPS }}$ \\
\hline \multirow[t]{9}{*}{1008} & $F s$ & $6 / 24$ & $1969-2012$ & $24.7 \pm 6.9$ & $28.5 \pm 8.8$ & $2.58 \pm 1.36$ & $2.71 \pm 1.36$ & 0.28 & 0.90 \\
\hline & $Q r$ & $6 / 27$ & $1972-2012$ & $17.1 \pm 4.5$ & $18.1 \pm 7.5$ & $1.77 \pm 0.95$ & $1.76 \pm 0.96$ & 0.44 & 0.95 \\
\hline & $P_{S}$ & $6 / 24$ & $1969-2012$ & $34.0 \pm 5.4$ & $33.0 \pm 12.7$ & $3.54 \pm 1.31$ & $3.57 \pm 1.34$ & 0.34 & 0.92 \\
\hline & $\mathrm{Pa}$ & $6 / 24$ & $1969-2012$ & $34.8 \pm 6.7$ & $32.7 \pm 5.7$ & $3.34 \pm 1.76$ & $3.19 \pm 1.76$ & 0.42 & 0.94 \\
\hline & $A g$ & $6 / 24$ & 1969-2012 & $43.1 \pm 8.2$ & $43.8 \pm 10.3$ & $4.60 \pm 1.91$ & $4.46 \pm 1.84$ & 0.31 & 0.91 \\
\hline & $P m$ & $6 / 24$ & $1969-2012$ & $36.6 \pm 7.5$ & $39.2 \pm 7.9$ & $3.57 \pm 1.94$ & $3.18 \pm 1.59$ & 0.39 & 0.94 \\
\hline & $A a$ & $6 / 24$ & $1975-2012$ & $27.6 \pm 7.7$ & $29.6 \pm 6.3$ & $3.28 \pm 1.65$ & $3.29 \pm 1.67$ & 0.41 & 0.93 \\
\hline & $L k$ & $6 / 24$ & $1969-2012$ & $31.4 \pm 3.5$ & $30.6 \pm 4.3$ & $2.90 \pm 1.45$ & $2.50 \pm 1.76$ & 0.49 & 0.96 \\
\hline & $\bar{X}$ & & & $31.2 \pm 8.0$ & $31.9 \pm 7.6$ & $3.20 \pm 0.82$ & $3.08 \pm 0.80$ & 0.39 & 0.93 \\
\hline \multirow[t]{8}{*}{1009} & $F s$ & $6 / 24$ & $1980-2012$ & $17.1 \pm 4.1$ & $16.2 \pm 5.9$ & $2.31 \pm 1.35$ & $2.33 \pm 1.35$ & 0.46 & 0.94 \\
\hline & $Q r$ & $6 / 24$ & $1970-2012$ & $18.0 \pm 3.2$ & $20.2 \pm 4.5$ & $1.86 \pm 0.82$ & $1.81 \pm 0.81$ & 0.44 & 0.94 \\
\hline & Ps & $6 / 24$ & $1969-2012$ & $33.0 \pm 6.8$ & $37.4 \pm 7.4$ & $3.45 \pm 1.53$ & $3.53 \pm 1.57$ & 0.36 & 0.93 \\
\hline & $\mathrm{Pa}$ & $6 / 24$ & $1970-2012$ & $28.9 \pm 6.9$ & $35.2 \pm 7.3$ & $3.35 \pm 1.59$ & $3.19 \pm 1.59$ & 0.32 & 0.90 \\
\hline & $A g$ & $6 / 24$ & $1972-2012$ & $31.6 \pm 7.0$ & $36.6 \pm 7.4$ & $3.50 \pm 1.61$ & $3.56 \pm 1.64$ & 0.44 & 0.94 \\
\hline & $A a$ & $6 / 24$ & $1980-2012$ & $23.5 \pm 7.6$ & $25.4 \pm 5.7$ & $3.30 \pm 1.87$ & $3.32 \pm 1.88$ & 0.36 & 0.91 \\
\hline & $L k$ & $6 / 24$ & $1967-2012$ & $32.2 \pm 3.6$ & $37.6 \pm 5.2$ & $2.91 \pm 1.61$ & $2.56 \pm 1.13$ & 0.45 & 0.95 \\
\hline & $\bar{X}$ & & & $26.3 \pm 6.8$ & $29.8 \pm 9.0$ & $2.95 \pm 0.64$ & $2.90 \pm 0.67$ & 0.40 & 0.93 \\
\hline \multirow[t]{9}{*}{1010} & $F s$ & $6 / 24$ & $1968-2012$ & $25.3 \pm 6.4$ & $27.2 \pm 7.4$ & $2.59 \pm 1.07$ & $2.58 \pm 1.07$ & 0.47 & 0.95 \\
\hline & $Q r$ & $6 / 25$ & $1970-2012$ & $21.9 \pm 4.3$ & $25.0 \pm 6.2$ & $2.26 \pm 1.15$ & $2.11 \pm 1.08$ & 0.40 & 0.94 \\
\hline & Ps & $6 / 24$ & $1967-2012$ & $27.6 \pm 7.2$ & $30.5 \pm 7.1$ & $2.76 \pm 1.46$ & $2.52 \pm 1.26$ & 0.39 & 0.94 \\
\hline & $\mathrm{Pa}$ & $6 / 24$ & $1969-2012$ & $28.7 \pm 10.3$ & $31.8 \pm 6.1$ & $3.04 \pm 1.84$ & $2.85 \pm 1.75$ & 0.46 & 0.95 \\
\hline & $A g$ & $6 / 24$ & $1968-2012$ & $36.8 \pm 7.2$ & $42.5 \pm 8.9$ & $3.70 \pm 1.64$ & $3.49 \pm 1.49$ & 0.34 & 0.92 \\
\hline & $P m$ & $6 / 26$ & 1969-2012 & $30.9 \pm 8.5$ & $33.9 \pm 8.5$ & $3.15 \pm 1.77$ & $2.83 \pm 1.42$ & 0.25 & 0.89 \\
\hline & $A a$ & $5 / 20$ & $1972-2012$ & $28.2 \pm 10.7$ & $32.9 \pm 13.6$ & $3.29 \pm 1.93$ & $3.16 \pm 1.87$ & 0.48 & 0.94 \\
\hline & $L k$ & $6 / 24$ & $1967-2012$ & $27.1 \pm 5.2$ & $30.9 \pm 4.0$ & $2.35 \pm 1.54$ & $2.01 \pm 1.24$ & 0.43 & 0.95 \\
\hline & $\bar{X}$ & & & $28.3 \pm 4.3$ & $31.8 \pm 5.2$ & $2.89 \pm 0.49$ & $2.69 \pm 0.50$ & 0.40 & 0.94 \\
\hline \multirow[t]{9}{*}{1011} & Fs & $6 / 30$ & $1971-2012$ & $21.9 \pm 11.4$ & $24.9 \pm 6.0$ & $2.46 \pm 1.57$ & $2.45 \pm 1.60$ & 0.32 & 0.92 \\
\hline & $Q r$ & $6 / 24$ & $1977-2012$ & $22.1 \pm 8.0$ & $21.0 \pm 6.0$ & $2.74 \pm 1.31$ & $2.74 \pm 1.31$ & 0.29 & 0.88 \\
\hline & Ps & $6 / 29$ & $1968-2012$ & $33.9 \pm 4.5$ & $36.1 \pm 5.9$ & $3.46 \pm 1.76$ & $3.10 \pm 1.40$ & 0.41 & 0.95 \\
\hline & $P a$ & $6 / 24$ & $1970-2012$ & $28.9 \pm 6.0$ & $33.0 \pm 5.0$ & $3.05 \pm 1.47$ & $2.87 \pm 1.31$ & 0.38 & 0.93 \\
\hline & $A g$ & $6 / 25$ & $1972-2012$ & $38.7 \pm 9.0$ & $44.6 \pm 9.8$ & $4.17 \pm 2.12$ & $4.15 \pm 2.10$ & 0.33 & 0.92 \\
\hline & $P m$ & $5 / 20$ & 1972-2012 & $38.0 \pm 9.1$ & $38.5 \pm 7.6$ & $3.86 \pm 1.99$ & $3.73 \pm 1.96$ & 0.49 & 0.94 \\
\hline & $A a$ & $6 / 26$ & $1974-2012$ & $28.1 \pm 7.7$ & $34.3 \pm 6.5$ & $3.47 \pm 1.83$ & $3.49 \pm 1.84$ & 0.37 & 0.93 \\
\hline & $L k$ & $6 / 26$ & $1968-2012$ & $33.1 \pm 3.8$ & $34.3 \pm 4.8$ & $3.08 \pm 1.84$ & $2.58 \pm 1.22$ & 0.44 & 0.95 \\
\hline & $\bar{X}$ & & & $30.6 \pm 6.5$ & $33.3 \pm 7.4$ & $3.29 \pm 0.57$ & $3.14 \pm 0.60$ & 0.38 & 0.93 \\
\hline \multirow[t]{2}{*}{1013} & $F s$ & $6 / 24$ & $1972-2012$ & $11.8 \pm 4.8$ & $9.2 \pm 6.1$ & $1.48 \pm 0.98$ & $1.50 \pm 1.00$ & 0.23 & 0.85 \\
\hline & $Q r$ & $6 / 24$ & $1970-2012$ & $12.8 \pm 4.4$ & $11.6 \pm 4.6$ & $1.37 \pm 0.64$ & $1.34 \pm 0.63$ & 0.54 & 0.96 \\
\hline
\end{tabular}




\begin{tabular}{lllllllll}
$P a$ & $6 / 24$ & $1972-2012$ & $17.7 \pm 5.9$ & $21.2 \pm 5.8$ & $2.05 \pm 1.49$ & $1.96 \pm 1.44$ & 0.33 & 0.91 \\
$A g$ & $6 / 24$ & $1972-2012$ & $21.4 \pm 7.9$ & $23.8 \pm 6.9$ & $2.27 \pm 1.47$ & $2.19 \pm 1.47$ & 0.50 & 0.96 \\
$P m$ & $6 / 24$ & $1972-2012$ & $22.9 \pm 4.5$ & $30.8 \pm 7.7$ & $2.61 \pm 1.30$ & $2.64 \pm 1.32$ & 0.42 & 0.94 \\
$A a$ & $6 / 24$ & $1973-2012$ & $20.4 \pm 7.1$ & $20.2 \pm 9.6$ & $2.34 \pm 1.19$ & $2.36 \pm 1.21$ & 0.40 & 0.93 \\
$L k$ & $6 / 24$ & $1968-2012$ & $23.8 \pm 1.6$ & $25.0 \pm 3.6$ & $2.24 \pm 1.60$ & $1.93 \pm 1.26$ & 0.49 & 0.96 \\
$\bar{X}$ & & & $18.7 \pm 4.8$ & $20.3 \pm 7.6$ & $2.05 \pm 0.46$ & $1.99 \pm 0.46$ & 0.42 & 0.93 \\
\hline$F s$ & $6 / 24$ & $1970-2012$ & $16.0 \pm 5.2$ & $14.7 \pm 6.8$ & $1.66 \pm 0.93$ & $1.59 \pm 0.93$ & 0.60 & 0.97 \\
$Q r$ & $6 / 24$ & $1969-2012$ & $14.9 \pm 4.0$ & $13.7 \pm 4.6$ & $1.41 \pm 0.84$ & $1.26 \pm 0.73$ & 0.66 & 0.98 \\
$P a$ & $6 / 24$ & $1971-2012$ & $19.8 \pm 5.2$ & $22.3 \pm 4.2$ & $2.17 \pm 1.12$ & $2.05 \pm 0.99$ & 0.59 & 0.97 \\
$A g$ & $6 / 24$ & $1972-2012$ & $26.1 \pm 7.9$ & $31.6 \pm 8.9$ & $2.89 \pm 1.44$ & $2.92 \pm 1.46$ & 0.46 & 0.95 \\
$P m$ & $6 / 24$ & $1971-2012$ & $27.5 \pm 5.5$ & $32.6 \pm 7.0$ & $2.80 \pm 1.45$ & $2.55 \pm 1.19$ & 0.49 & 0.96 \\
$A a$ & $6 / 24$ & $1972-2012$ & $21.7 \pm 4.5$ & $22.9 \pm 7.0$ & $2.44 \pm 1.20$ & $2.44 \pm 1.24$ & 0.51 & 0.96 \\
$L k$ & $6 / 24$ & $1968-2012$ & $24.1 \pm 3.1$ & $27.3 \pm 4.2$ & $2.24 \pm 1.48$ & $1.75 \pm 0.64$ & 0.66 & 0.98 \\
$\bar{X}$ & & & $21.4 \pm 4.8$ & $23.6 \pm 7.5$ & $2.23 \pm 0.55$ & $2.08 \pm 0.59$ & 0.57 & 0.97
\end{tabular}

$651 \quad{ }^{a} F s=$ Fagus sylvatica, $Q r=$ Quercus robur, Ps $=$ Picea sitchensis, $P a=$ Picea abies, $A g=$ Abies grandis, Pm $=$ Pseudotsuga menziesii, Aa $=$ Abies

$652 a l b a, L k=$ Larix kaempferi. ${ }^{\mathrm{b}}$ common period to all sampled trees; ${ }^{\mathrm{c}}$ Tree DBH $=$ mean DBH of sample trees; ${ }^{\mathrm{d}} \mathrm{Stand}$ DBH $=$ mean DBH of all the 653 standing trees in 2012; ${ }^{\mathrm{e}}$ period $1975-2012$; Rbar = mean inter-series correlation; EPS = expressed population signal. 
654 Table 3: Estimators of resistance (Rt), resilience (Rs) and relative resilience (RRs) after the drought events.

\begin{tabular}{llll}
\hline Species $^{\mathrm{a}}$ & $\mathrm{Rt}$ & $\mathrm{Rs}$ & $\mathrm{RRs}$ \\
\hline$F s$ & $0.839 \pm 0.021$ & $1.033 \pm 0.017 \mathrm{~b}$ & $0.194 \pm 0.023$ \\
$Q r$ & $0.874 \pm 0.021$ & $1.104 \pm 0.017 \mathrm{a}$ & $0.230 \pm 0.023$ \\
$P S$ & $0.800 \pm 0.025$ & $1.007 \pm 0.021 \mathrm{bc}$ & $0.206 \pm 0.028$ \\
$P a$ & $0.812 \pm 0.020$ & $1.012 \pm 0.017 \mathrm{bc}$ & $0.202 \pm 0.023$ \\
$A g$ & $0.821 \pm 0.020$ & $0.972 \pm 0.017 \mathrm{c}$ & $0.151 \pm 0.022$ \\
$P m$ & $0.873 \pm 0.023$ & $1.046 \pm 0.019 \mathrm{~b}$ & $0.172 \pm 0.025$ \\
$A a$ & $0.858 \pm 0.025$ & $1.058 \pm 0.018 \mathrm{ab}$ & $0.200 \pm 0.024$ \\
$L k$ & $0.807 \pm 0.020$ & $0.978 \pm 0.017 \mathrm{c}$ & $0.171 \pm 0.022$ \\
$P$-value & 0.068 & $<.0001$ & 0.330
\end{tabular}

$655{ }^{a} F s=$ Fagus sylvatica, $Q r=$ Quercus robur, Ps $=$ Picea sitchensis, $P a=$ Picea abies, Ag $=$ Abies grandis, Pm $=$ Pseudotsuga menziesii, Aa $=$ Abies $656 \quad$ alba, Lk = Larix kaempferi.

$657 \mathrm{Rt}=$ Resistance $=$ the ratio between growth during drought and the growth prior to drought, i.e., Dr/PreDr; Rs $=$ Resilience $=$ the ability to reach

658 performance levels observed prior to drought, i.e., PostDr/PreDr; RRs = Relative resilience = the resilience weighted by the reduction experienced

659 during drought, i.e., : RRs $=($ PostDr $-D r) / P r e D r$, according to Lloret et al. (2011).

$660 \mathrm{a}, a b, b, b c, c$ indicate significantly different estimators of the general linear model $(P<0.05$, Tukey test). 
661 Table 4: Estimators of the departure of the ring width index $(\triangle R W I)$ as obtained from the superposed epoch analysis 662 (SEA) of the selected drought years $(1976,1992$ and 2006).

\begin{tabular}{ll}
\hline Sites & $\Delta R W I$ \\
\hline 1013 & $-0.809 \pm 0.134 \mathrm{a}$ \\
1010 & $-0.894 \pm 0.134 \mathrm{a}$ \\
1011 & $-1.163 \pm 0.134 \mathrm{a}$ \\
1009 & $-1.195 \pm 0.134 \mathrm{a}$ \\
1014 & $-1.301 \pm 0.134 \mathrm{~b}$ \\
1008 & $-1.500 \pm 0.134 \mathrm{~b}$ \\
DF & 25 \\
$P$-value & 0.013 \\
\hline
\end{tabular}

$663 \quad$ a, indicate significantly different estimators of the general linear model $(P<0.05$, Tukey test). 
Table 5: Growth projection as obtained from the multiple regression model relating $R W I$ with climate for the eight 665 species considered in this study. The predicted $R W I$ for the periods A (2011-2040), B (2041-2070) and C (2071-2100) are based on the RCP4.5 scenario and shown as the percentage deviation from the mean $R W I$ from the reference period 667 1991-2009.

\begin{tabular}{|c|c|c|c|c|c|c|c|c|c|c|c|}
\hline \multirow[b]{2}{*}{ Species a } & \multirow[b]{2}{*}{ Model $^{\text {b }}$} & \multirow[b]{2}{*}{ Estimate \pm sd } & \multirow{2}{*}{$\begin{array}{l}\text { CI range }^{c} \\
5-95 \%\left[{ }^{\circ} \mathrm{C}\right. \\
\left.\text { or } \mathrm{mm}^{\circ} \mathrm{C}^{-1}\right]\end{array}$} & \multirow{2}{*}{$\begin{array}{c}\text { Reference }^{\mathrm{d}} \\
1991-2009 \\
{\left[{ }^{\circ} \mathrm{C} \text { or }\right.} \\
\left.\mathrm{mm}^{\circ} \mathrm{C}^{-1}\right] \\
\end{array}$} & \multicolumn{3}{|c|}{$\begin{array}{l}\text { Period mean climate } \\
{\left[{ }^{\circ} \mathrm{C} \text { or } \mathrm{mm}^{\circ} \mathrm{C}^{-1}\right]}\end{array}$} & \multicolumn{4}{|c|}{ Growth change $^{\mathrm{e}}[\%]$} \\
\hline & & & & & $\mathbf{A}$ & B & $\mathbf{C}$ & & $\mathbf{A}$ & B & $\mathrm{C}$ \\
\hline \multirow[t]{3}{*}{ Fs } & Intercept & $1.665 \pm 0.128$ & & - & - & - & - & & - & - & - \\
\hline & Tm6 & $-0.048 \pm 0.009$ & $11.9-16.3$ & 14.4 & 15.9 & 16.7 & 17.1 & & -8 & -12 & -13 \\
\hline & & & & & & & & $\Sigma$ & -8 & -12 & -13 \\
\hline \multirow[t]{5}{*}{$Q r$} & Intercept & $0.728 \pm 0.133$ & & - & - & - & - & & - & - & - \\
\hline & lag1Tm10 & $0.034 \pm 0.006$ & $7.0-12.8$ & 9.0 & 10.3 & 11.1 & 11.5 & & 5 & 7 & 9 \\
\hline & $\operatorname{Tm} 35$ & $0.055 \pm 0.009$ & $5.1-9.2$ & 7.0 & 7.5 & 8.2 & 8.5 & & 3 & 7 & 9 \\
\hline & Tm9 & $-0.034 \pm 0.008$ & $11.3-15.9$ & 13.6 & 14.1 & 14.8 & 15.2 & & -2 & -4 & -6 \\
\hline & & & & & & & & $\Sigma$ & 6 & 10 & 12 \\
\hline \multirow[t]{3}{*}{ Ps } & Intercept & $0.834 \pm 0.003$ & & - & - & - & - & & - & - & - \\
\hline & $\mathrm{mt} 67$ & $0.033 \pm 0.005$ & $0.9-8.7$ & 4.7 & 4.7 & 4.5 & 4.3 & & 0 & 0 & -1 \\
\hline & & & & & & & & $\Sigma$ & $\mathbf{0}$ & 0 & -1 \\
\hline \multirow[t]{6}{*}{$P a$} & Intercept & $1.604 \pm 0.127$ & & - & - & - & - & & - & - & - \\
\hline & lag1Tm910 & $-0.046 \pm 0.008$ & $9.9-13.7$ & 11.3 & 12.2 & 12.9 & 13.3 & & -4 & -7 & -9 \\
\hline & $\operatorname{Tm} 35$ & $0.029 \pm 0.009$ & 4.9-9.2 & 7.0 & 7.5 & 8.2 & 8.5 & & 1 & 3 & 4 \\
\hline & Tm6 & $-0.031 \pm 0.008$ & $11.9-16.4$ & 14.4 & 15.9 & 16.7 & 17.1 & & -5 & -7 & -8 \\
\hline & mt67 & $0.029 \pm 0.004$ & $1.0-8.6$ & 4.8 & 4.8 & 4.6 & 4.3 & & 0 & -1 & -1 \\
\hline & & & & & & & & $\Sigma$ & -8 & -12 & -15 \\
\hline \multirow[t]{4}{*}{$A g$} & Intercept & $1.405 \pm 0.085$ & & - & - & - & - & & - & - & - \\
\hline & lag1Tm910 & $-0.040 \pm 0.007$ & $9.8-13.7$ & 11.3 & 12.2 & 12.9 & 13.3 & & -4 & -7 & -8 \\
\hline & $\mathrm{mt} 6$ & $0.027 \pm 0.005$ & $-0.2-4.8$ & 2.5 & 2.2 & 2.1 & 2.0 & & -1 & -1 & -1 \\
\hline & & & & & & & & $\Sigma$ & -4 & -8 & -10 \\
\hline \multirow[t]{5}{*}{$P m$} & Intercept & $1.337 \pm 0.127$ & & - & - & - & - & & - & - & - \\
\hline & lag1Tm89 & $-0.035 \pm 0.009$ & $13.0-17.1$ & 15.3 & 15.7 & 16.4 & 16.9 & & -2 & -5 & -7 \\
\hline & $\operatorname{Tm} 34$ & $0.036 \pm 0.007$ & $2.6-7.5$ & 4.8 & 5.1 & 5.8 & 6.2 & & 1 & 4 & 6 \\
\hline & $\operatorname{lag} 1 \mathrm{mt} 56$ & $0.020 \pm 0.005$ & $1.3-7.9$ & 4.7 & 4.5 & 4.3 & 4.3 & & -1 & -1 & -1 \\
\hline & & & & & & & & $\Sigma$ & -1 & -2 & -2 \\
\hline \multirow[t]{4}{*}{$A a$} & Intercept & $1.056 \pm 0.004$ & & - & - & - & - & & - & - & - \\
\hline & $\mathrm{mt} 6$ & $0.034 \pm 0.007$ & $-0.2-4.8$ & 2.5 & 2.2 & 2.1 & 2.0 & & -1 & -1 & -2 \\
\hline & $\operatorname{lag} 1 \mathrm{mt} 37$ & $-0.010 \pm 0.002$ & $7.3-20.1$ & 12.7 & 13.2 & 12.7 & 12.5 & & -1 & 0 & 0 \\
\hline & & & & & & & & $\Sigma$ & -1 & -1 & -2 \\
\hline \multirow[t]{5}{*}{$L k$} & Intercept & $1.785 \pm 0.125$ & & - & - & - & - & & - & - & - \\
\hline & $\operatorname{lag} 1 \mathrm{Tm} 7$ & $-0.024 \pm 0.006$ & $13.7-19.4$ & 17.0 & 17.3 & 18.1 & 18.5 & & -1 & -3 & -4 \\
\hline & Tm6 & $-0.036 \pm 0.008$ & $11.9-16.3$ & 14.4 & 15.9 & 16.7 & 17.1 & & -6 & -9 & -10 \\
\hline & $\mathrm{mt} 6$ & $0.045 \pm 0.007$ & $-0.1-4.7$ & 2.52 & 2.24 & 2.11 & 2.02 & & -1 & -2 & -2 \\
\hline & & & & & & & & & & & \\
\hline
\end{tabular}


$\sum \quad-8$

$-13$

$668{ }^{\mathrm{a}} \mathrm{Fs}=$ Fagus sylvatica, $Q r=$ Quercus robur, $P s=$ Picea sitchensis, $P a=$ Picea abies, $A g=$ Abies grandis, Pm $=$ Pseudotsuga menziesii, Aa $=$ Abies $669 \quad a l b a$, Lk $=$ Larix kaempferi.

$670{ }^{\mathrm{b}}$ Climate variables: lag1Tm7, previous-year July temperature; lag1 Tm89, previous-year average temperature for August and September; lag1Tm910, previous-year average temperature for September and October; lag1Tm10, previous-year October temperature; Tm34, average temperature for March and April; Tm35, average temperature for March, April and May; Tm6, June temperature; Tm9, September temperature; lag1 mt37, previous-year cumulated $m t$-indices for March to July; lag1mt56, previous-year cumulated $m t$-indices for May and previous-year June; mt6, $m t$ - index for June; $\mathrm{mt} 67$, cumulated $m t$ - index for June and July.

675 c 95\% confidence interval of the climate variables 1972-2012 used for the development of the RWI prediction model.

676 d reference period 1991-2009. Mean of estimates for field trials where the respective species are represented.

$677{ }^{\mathrm{e}}$ deviation from reference period 1991-2009. 
679 Fig. 1. Map of projected annual temperature and June and July aridity-humidity index anomalies (DI index) for the 680 period 2071-2100 compared to the reference period 1991-2009. $m t=P /(T m+10)$, where $P$ is the monthly sum of 681 precipitation and $T m$ is the average temperature in degree Celsius according to De Martonne (1926). Blue dots indicate 682 the location of the 13 field trials, and those with a coloured number refer to the selected field trials. Coloured triangles 683 (conifer) and circles (broadleaf) indicate the species considered at each site. Climate diagram refers to the average 684 monthly precipitation and temperature of six study sites (period 1991-2009).

685

686 Fig. 2. Relationship of average ring width grouped by year and sites for the period 1975 to 2012. Lines indicate the 687 results of the linear regression.

688

689 Fig. 3. Bootstrapped climate-growth correlation coefficients between the tree-ring indexes and a) monthly drought 690 index $(D I)$ and $\mathbf{b})$ temperature from June of the previous year to September of the current year $(P<0.05)$. Black dots 691 indicate a significant correlation at $P<0.05$.

692

693 Fig. 4. Results from the superposed epoch analysis (SEA) showing departures from the mean ring-width index for the 694 dry years $(\operatorname{lag}=0), 3$ years before the dry years $(\operatorname{lag}=-3)$ and three years after the dry years $(\operatorname{lag}=3)$. Black dots 695 indicate a significant departure from the mean at $P<0.05$. The number of sites with significant departures at dry years 696 for each species is $F s$ (3), $Q r$ (2), $P S$ (3), $P a$ (5), $A g$ (4), $P m$ (2), $A$ a (2), and $L k$ (3). 697 
Fig. 1

\begin{tabular}{|l} 
SPECIES \\
Fs $=F$. sylvatica \\
$Q r=Q$. robur \\
$A s=P$. sitchensis \\
$A P=P$. abies \\
$A g=A$. grandis \\
$A P m=P$. menziesii \\
$A a=A$. alba \\
$\triangle A k=L$. kaempferi
\end{tabular}

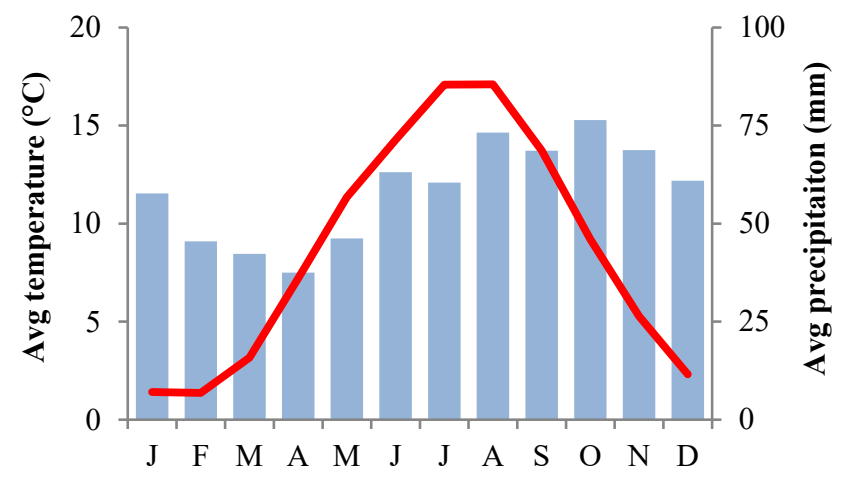

\section{TEMPERATURE}

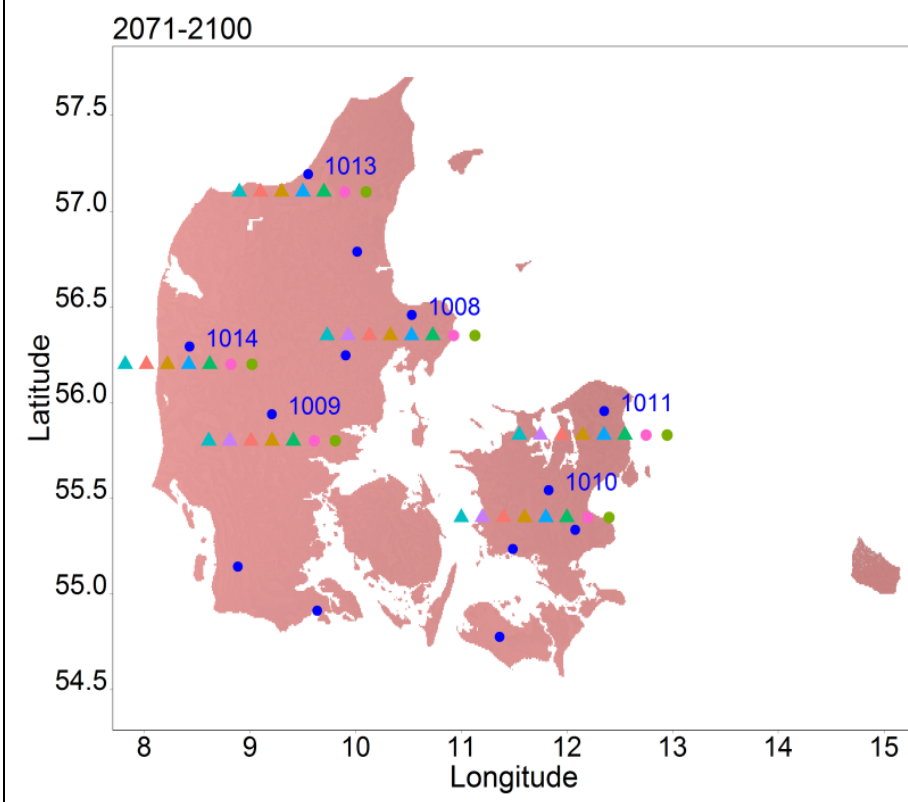

\section{DROUGHT INDEX}

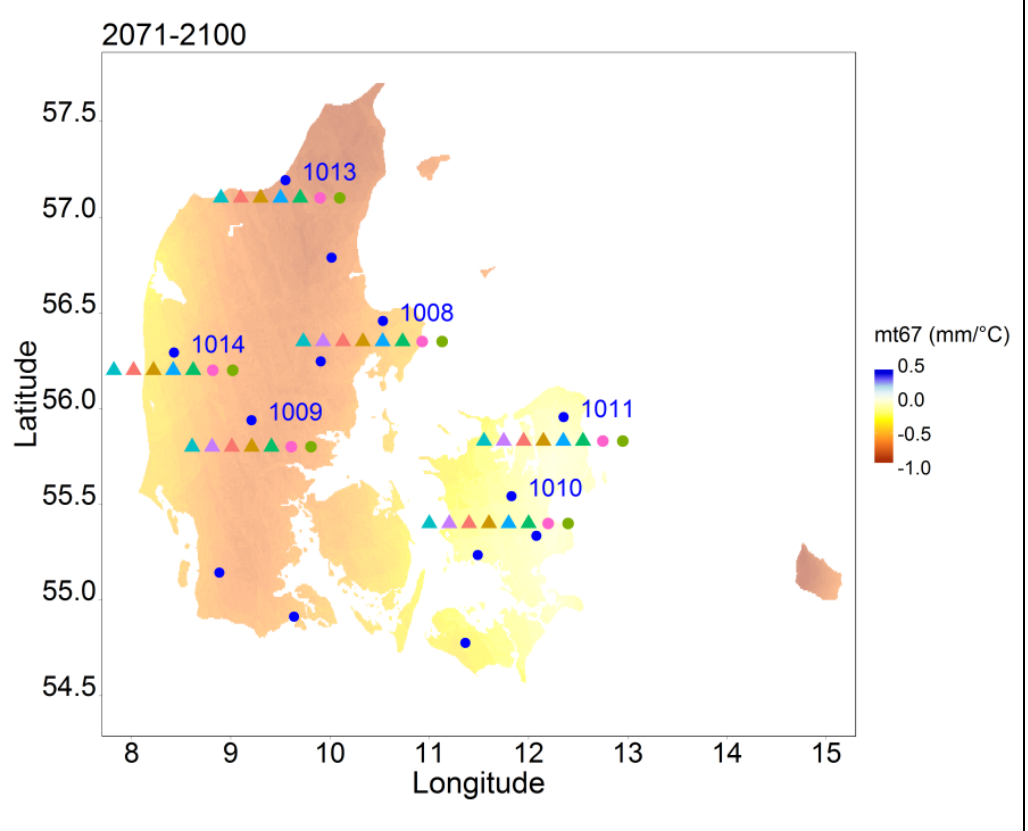


Fig. 2

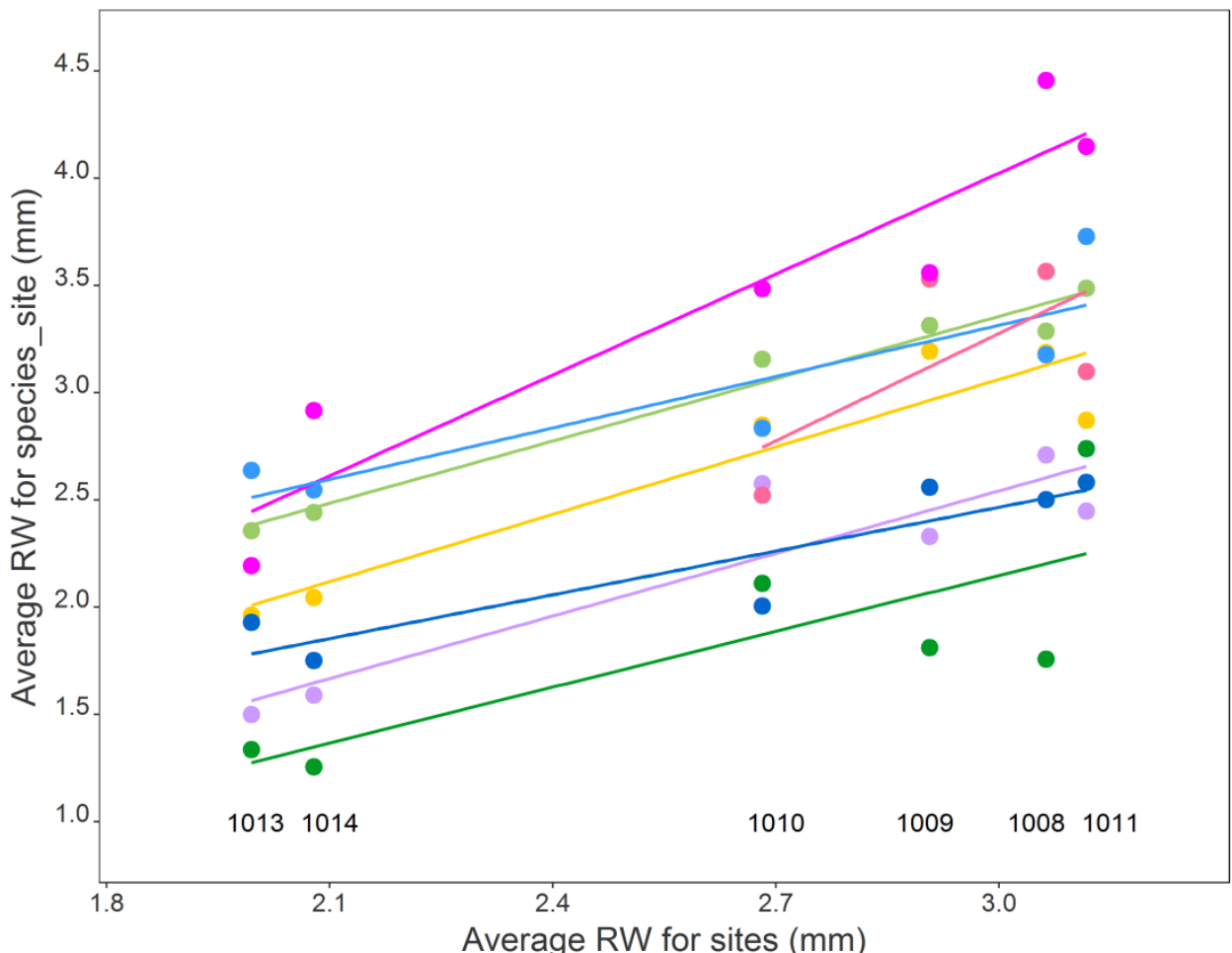

species

F. sylvatica

- Q. robur

P. sitchensis

P. abies

- A. grandis

- P. menziesii

- A. alba

- L. kaempferi 
Fig. 3a

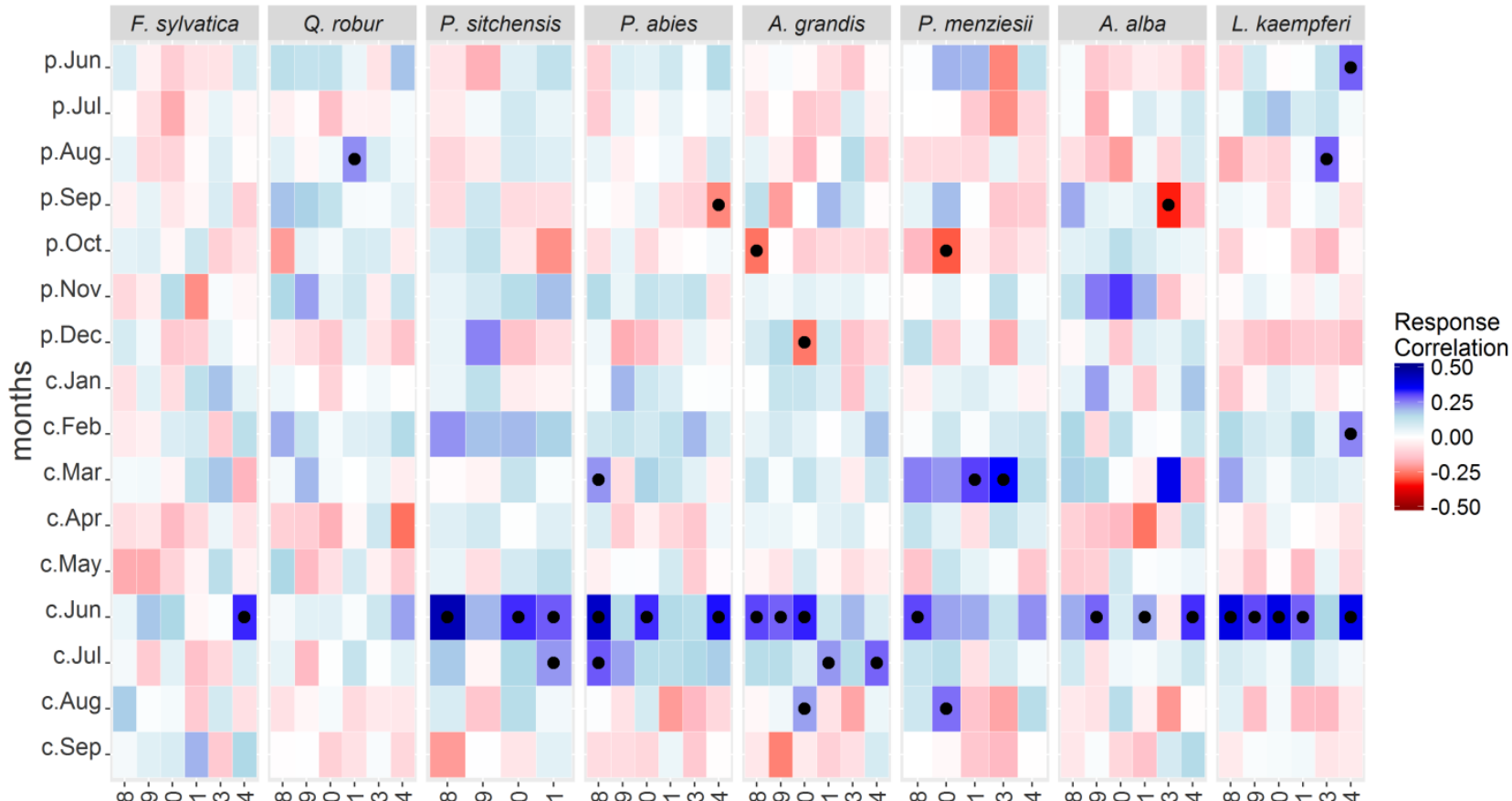

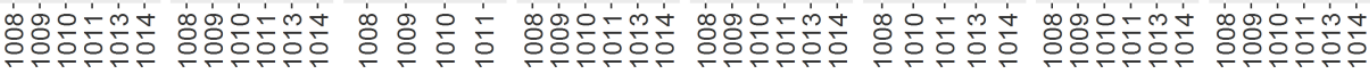
site

Fig. 3b

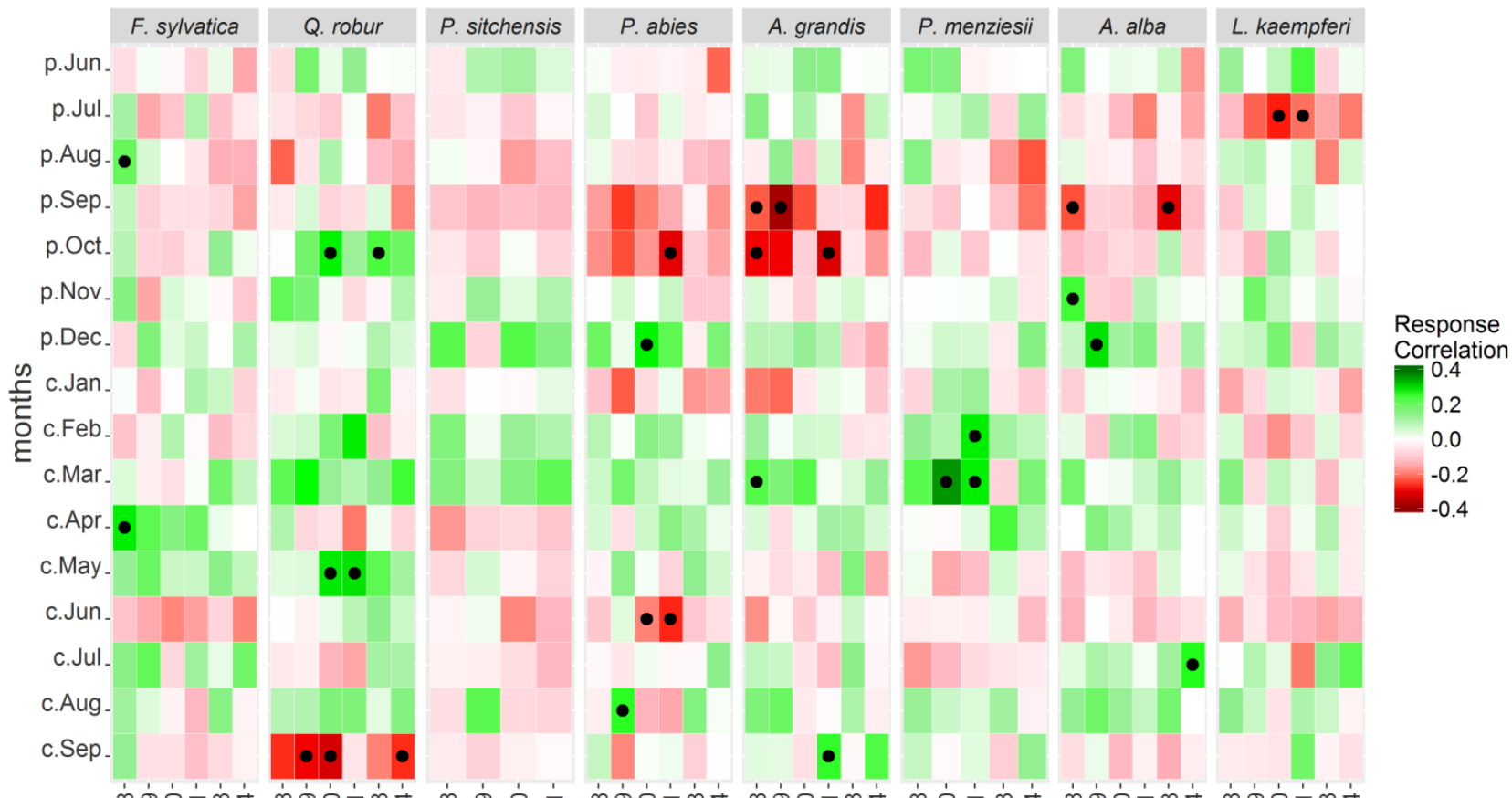

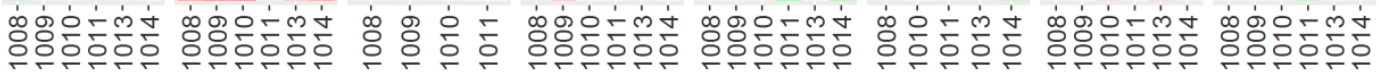


Fig. 4
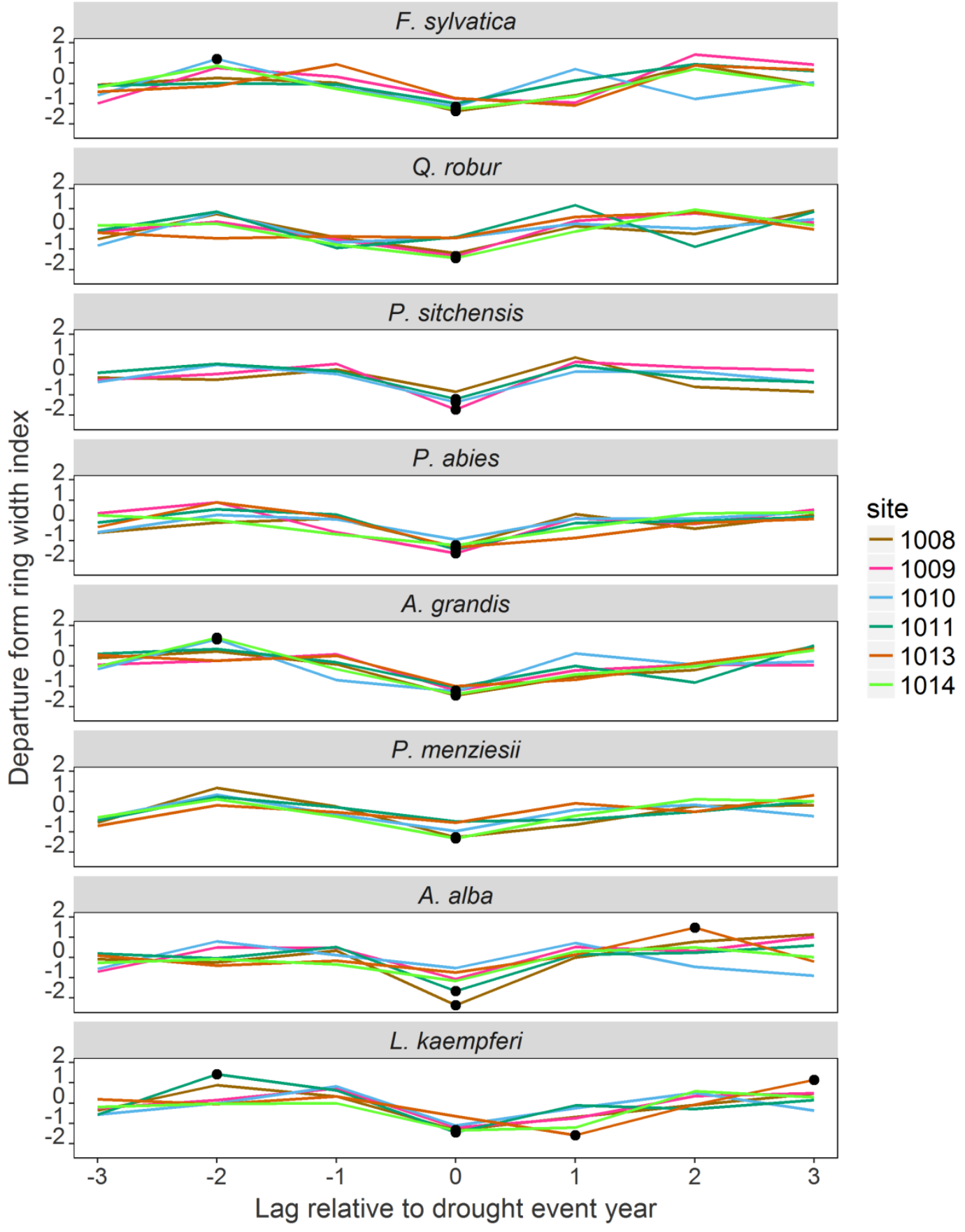